\title{
Shallow non-inversion tillage in organic farming maintains crop yields and increases soil $\mathrm{C}$ stocks: a meta-analysis
}

\author{
Julia Cooper $^{1} \cdot$ Marcin Baranski $^{1} \cdot$ Gavin Stewart $^{1} \cdot$ Majimcha Nobel-de Lange $^{1}$ • \\ Paolo Bàrberi ${ }^{2}$ - Andreas Fließbach ${ }^{3}$ • Josephine Peigné ${ }^{4}$ - Alfred Berner ${ }^{3}$. \\ Christopher Brock $^{5}$ • Marion Casagrande ${ }^{4}$ - Oliver Crowley ${ }^{6,7}$ - Christophe David ${ }^{4}$. \\ Alex De Vliegher ${ }^{8}$. Thomas F. Döring ${ }^{6,9}$ • Aurélien Dupont ${ }^{10}$ - Martin Entz ${ }^{11}$. \\ Meike Grosse $^{12}$. Thorsten Haase ${ }^{13}$ - Caroline Halde ${ }^{11,14}$ - Verena Hammerl ${ }^{15}$. \\ Hilfred Huiting $^{16}$ • Günter Leithold ${ }^{5}$ - Monika Messmer ${ }^{3}$ Michael Schloter $^{15}$. \\ Wijnand Sukkel $^{16}$ • Marcel G. A. van der Heijden ${ }^{17}$ - Koen Willekens ${ }^{8}$. \\ Raphaël Wittwer $^{17} \cdot$ Paul Mäder $^{3}$
}

Accepted: 27 January 2016 / Published online: 3 March 2016

C The Author(s) 2016. This article is published with open access at Springerlink.com

\begin{abstract}
Reduced tillage is increasingly promoted to improve sustainability and productivity of agricultural systems. Nonetheless, adoption of reduced tillage by organic farmers has been slow due to concerns about nutrient supply, soil structure, and weeds that may limit yields. Here, we compiled the results from both published and unpublished research comparing deep or shallow inversion tillage, with various categories of reduced tillage under organic management. Shallow refers to less than $25 \mathrm{~cm}$. We found that (1) division
\end{abstract}

Julia Cooper

Julia.Cooper@ncl.ac.uk

1 School of Agriculture, Food and Rural Development, Newcastle University, Kings Road, Newcastle NE1 7RU, UK

2 Scuola Superiore Sant'Anna, Institute of Life Sciences, Piazza Martiri della Libertà 33, 56127 Pisa, Italy

3 Research Institute of Organic Agriculture (FiBL), Ackerstrasse, CH-5070 Frick, Switzerland

4 ISARA-Lyon, Université de Lyon, 23 rue Jean Baldassini, 69007 Lyon, France

5 Organic Farming, Justus Liebig University Giessen, Karl-Glöckner-Str. 21c, 35394 Giessen, Germany

6 Organic Research Centre (ORC), Elm Farm, Newbury, Berkshire RG20 0HR, UK

7 Centre for Agri-Environmental Research, School of Agriculture, Policy and Development, The University of Reading Earley Gate, Reading RG6 6AR, UK

8 Plant Sciences Unit, Crop Husbandry and Environment, Institute for Agricultural and Fisheries Research (ILVO), Merelbeke, Belgium of reduced tillage practices into different classes with varying degrees of intensity allowed us to assess the trade-offs between reductions in tillage intensity, crop yields, weed incidence, and soil C stocks. (2) Reducing tillage intensity in organic systems reduced crop yields by an average of $7.6 \%$ relative to deep inversion tillage with no significant reduction in yield relative to shallow inversion tillage. (3) Among the different classes of reduced tillage practice, shallow noninversion tillage resulted in non-significant reductions in yield

9 Department of Agronomy and Crop Science, Humboldt University Berlin, Albrecht-Thaer-Weg 5, 14195 Berlin, Germany

10 Agriculture and Territories, Chambres d'agriculture de Bretagne, 4 Avenue du Chalutier Sans Pitié, BP 10540, 22195 Plerin Cedex, France

11

Department of Plant Science, University of Manitoba, Winnipeg, Canada R3T 2N2

12 University of Kassel, Department of Organic Farming and Cropping, Nordbahnhofstr. 1a, 37213 Witzenhausen, Germany

13 Landesbetrieb Landwirtschaft Hessen, Beratungsteam Ökologischer Landbau, Kölnische Str. 48-50, 34117 Kassel, Germany

14 Département de Phytologie, Université Laval, Québec City, Canada G1V 0A6

15 Helmholtz Zentrum München (HMGU), Research Unit Environmental Genomics, Ingolstädter Landstr. 1, 85764 Neuherberg, Germany

16 Applied Plant Research (WUR-APR), Wageningen University and Research Centre, Lelystad, The Netherlands

17 Plant-Soil Interactions, Institute for Sustainability Sciences, Agroscope, Reckenholzstrasse 191, CH-8046 Zürich, Switzerland 
relative to deep inversion; whereas deep non-inversion tillage resulted in the largest yield reduction, of $11.6 \%$. (4) Using inversion tillage to only a shallow depth resulted in minimal reductions in yield, of $5.5 \%$, but significantly higher soil C stocks and better weed control. This finding suggests that this is a good option for organic farmers wanting to improve soil quality while minimizing impacts on yields. (5) Weeds were consistently higher, by about $50 \%$, when tillage intensity was reduced, although this did not always result in reduced yields.

Keywords No-till · Organic farming · Conservation tillage · Conservation agriculture · Meta-analysis · Crop yield .

Weeds $\cdot$ Soil $\mathrm{C} \cdot$ Reduced tillage $\cdot$ Minimum tillage

\section{Introduction}

\subsection{Current status of reduced tillage practices in the organic sector}

Reduced tillage intensity is one of the key components of conservation agriculture systems promoted by the Food and Agriculture Association of the United Nations to conserve, improve, and make more efficient use of natural resources (Food and Agriculture Organization of the United Nations 2015). The other two essential components of conservation agriculture are maximum soil cover and diversified crop rotations. Conservation agriculture practices not only reduce soil degradation but also contribute to sustained agricultural production, particularly in areas where soils are fragile and at risk of declining quality (Hobbs et al. 2008).

The use of diverse crop rotations and mulching are fundamental concepts within organic agriculture (Lampkin and Measures 2001); however, implementation of reduced tillage practices is less commonly accepted. Bàrberi (2006) explains that tillage is important in organic agriculture for a number of reasons including incorporation of organic residues into the soil to facilitate more rapid mineralization and release of nutrients to the crop. Biomass incorporation into the soil may also reduce some soilborne pest and pathogen loads (Liebman and Davis 2000). One of the most important roles of tillage in organic systems is for the control of weed populations (Peigné et al. 2007). Although weed control without herbicides is possible, there are challenges when combining organic practices with reductions in tillage intensity, and frequently crop yields are compromised.

The real and perceived challenges of reducing or eliminating tillage within organic systems has led to slower adoption of reduced and no-till in the organic community in Europe compared with the conventional sector (Mäder and Berner 2012). There are no precise figures available on numbers of organic farmers practicing conservation agriculture in Europe; however, numbers are expected to be very low. A survey in
Germany found that only $6 \%$ of the sample group (367 arable organic farmers) tilled the soil without a plough and that $22 \%$ were using shallow (less than $15 \mathrm{~cm}$ ) tillage (Fig. 1; Wilhelm et al. 2011). Furthermore, a recent targeted survey in Europe identified organic farmers practicing components of conservation agriculture and indicated a broad diversity of reduced tillage practices among this group (Peigné et al. 2015). Eighty-nine percent of surveyed organic farmers practicing conservation agriculture used some form of reduced tillage defined as any tillage shallower than the standard conventional ploughing practice and/or a non-inversion method, but only $27 \%$ of the organic farmers practicing conservation agriculture used no-till. The survey highlighted the challenges in weed management with reduced tillage, and also the need for deep tillage at some phases of the rotation to incorporate green manures and ley crops.

As highlighted by Mäder and Berner (2012), since the 1990s, several important experiments were established in Europe to investigate the use of reduced tillage systems under organic practices. In addition, results from some studies in the Mediterranean region (e.g., Bilalis et al. 2012b) and North America (e.g., Luna et al. 2012) have recently been published. In this study, we compiled results of published data, as well as raw data obtained from collaborators in Europe and North America, to allow a comprehensive meta-analysis of experimental data on the use of reduced tillage in organic farming systems.

\subsection{Study objectives}

The study was undertaken with the overall aim to identify optimal management practices for successful implementation of reduced tillage in organic farming systems. Note that "successful implementation" implies maximum yields, minimum weed incidence, and maximum SOC stocks.

The following specific questions were addressed in the meta-analysis:

1. What is the magnitude of the effect of reduced tillage intensity on crop yields in organic systems?

2. Is this effect consistent across all environments (soil types and climatic zones)?

3. Are there certain management practices that can be used to enhance production under reduced tillage intensity in organic systems, i.e., crop rotation, crop choice (current and previous year), use of mechanical weeding?

4. Are the impacts of reduced tillage on yield in organic systems stable over time?

5. Is it really weed incidence that is causing yield reductions? Or could there be other factors?

6. Does using reduced tillage intensity in organic systems increase soil organic $\mathrm{C}$ above the levels already achieved by organic practice? 
Fig. 1 Implements commonly used by organic farmers practicing conservation agriculture in Europe: a Researchers at the Research Institute of Organic Agriculture in Switzerland examining a chisel plough with stern (star) roller. b A roller crimper used for destroying cover crops and leys in organic no-till systems
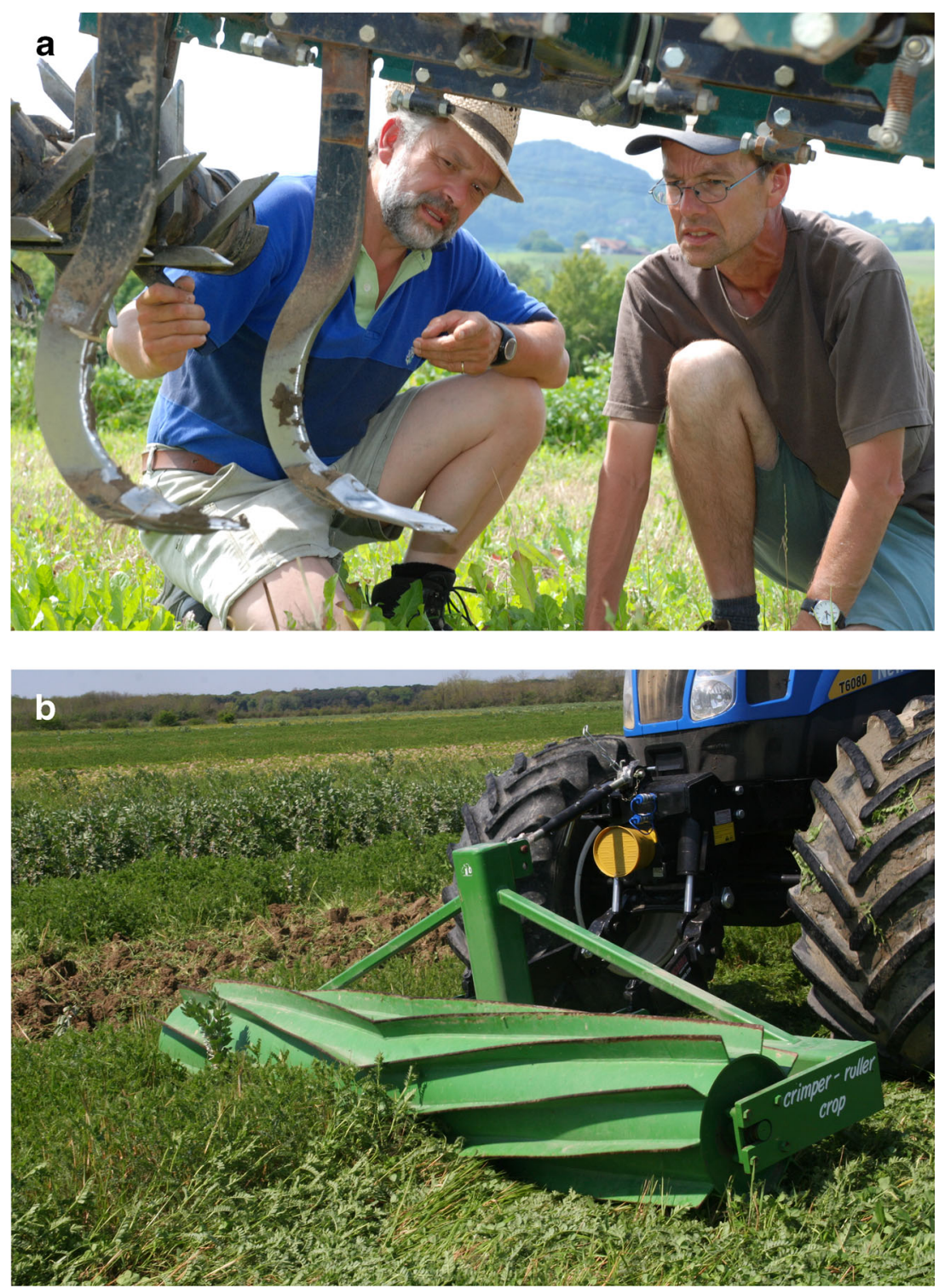

\section{Reduced tillage in organic systems}

\subsection{Impact on crop yields}

Reducing tillage intensity in conventional farming systems can impact crop yields although the direction and magnitude of this effect varies with climate, crop rotation, and soil type (Soane et al. 2012). A 2010 meta-regression study found an overall yield reduction across conventional cropping systems using conservation tillage in Europe of $4.5 \%$ (Van den Putte et al. 2010). More recently, Pittelkow et al. (2014) concluded that implementing no-till practices without the other two cornerstones of conservation agriculture (residue retention and crop rotation) resulted in yield reductions across all climates of $\sim 10 \%$, although gains in yield of almost $10 \%$ were achieved when no-till was combined with residue retention and crop rotation in dry climates. Implementing reduced tillage methods in organic farming may be more challenging due to issues with delayed and limited mineralization of nutrients from organic matter which cannot be addressed by inputs of synthetic fertilizers, as well as increased pressure from weeds (Peigné et al. 2007).

It is particularly important that the yield implications of reducing tillage in organic systems are quantified, since crop yields under organic management for many crops may already be significantly lower than conventional. Meta-analyses by Seufert et al. (2012) and Ponisio et al. (2015) indicated that yields of organic cereals were from 19 to $26 \%$ lower than conventional. However, these authors highlighted the potential to minimize this yield gap by using multicropping and diverse rotations. It is essential that the implementation of reduced tillage in organic systems does not further limit 
yields; therefore, environments and management practices that allow organic yields to be maintained or increased under reduced tillage need to be identified.

\subsection{Impact on weeds}

Reduced tillage concentrates weed seeds in surface soil layers and creates increased opportunities for germination and emergence, leading to increases in weed abundance (Légère et al. 2011). As a consequence, direct weed control methods such as mechanical weeding in organic systems, need to be particularly effective to prevent a progressive buildup of the weed seedbank and increased weed infestation in the long term (Melander et al. 2013). This problem is exacerbated in organic farming, where use of synthetic herbicides is forbidden.

As an alternative to herbicides, organic farmers rely on mechanical methods as well as well-planned and diversified crop rotations to keep weeds under reasonable control (Amossé et al. 2013). Diversification of the crop rotation and appropriate timing of management interventions creates a sequence of ecological disturbances which impedes (i) completion of the life cycle for the vast majority of weed species and (ii) selection of "crop mimics," i.e., weed species well adapted to the prevailing disturbance regime (Bàrberi 2002). Limiting tillage in organic reduced tillage systems makes weed control still more challenging. Researchers at the Rodale Institute in Pennsylvania and the USDA in Beltsville, MD, have been addressing this problem by developing systems for organic farmers that combine reduced tillage with weed suppressive cover crops, mulches, or associated crops. These systems can be effective at limiting annual weed growth in the subsequent crop; however, control of perennial weeds remains a challenge (Mirsky et al. 2012). Researchers in the American Midwest are also developing systems that use weed suppressing cover crops which are destroyed in a timely fashion by a roller crimper or sickle bar mower; in some cases, a preceding cover crop of rye can result in almost complete elimination of weeds in the subsequent crop (Silva 2014).

The problem of perennial weeds in organic no-till systems may result from a dramatic shift in weed community composition so that relative abundance of grasses, winddisseminated annuals, biennials, and perennials becomes progressively higher in a short time (Bàrberi and Lo Cascio 2001). The lack of severe soil disturbance allows the secondary succession of in-field vegetation to go beyond the initial stage characterised by annuals (Zanin et al. 1997). This was observed by Armengot et al. (2015) who reported a trend toward higher populations of perennial weeds over time in a long-term organic reduced tillage experiment. These ongoing problems have led to the adoption of hybrid systems where no-till is used for selected annual crops in the cropping sequence, e.g., spring crops like soya bean and corn, with reduced tillage during other crop phases across a rotation (Carr et al. 2013).

\subsection{Impact on soil C stocks}

The increase in surface soil $\mathrm{C}$ concentrations under no-till has been well documented (West and Post 2002); however, evidence for increases in the quantity of $\mathrm{C}$ stored (C stocks) in soils under no-till has been less consistent. Depth of sampling is crucial with studies where sampling is done to a shallower depth more likely to detect an increase in stocks under no-till (e.g., Angers and Eriksen-Hamel 2008), while deeper sampling usually results in few differences compared to full inversion tillage (Baker et al. 2007). Soil C can become stratified under no-till with concentrations higher than conventional tillage in the top soil layer, but lower concentrations at deeper depths, resulting in no net difference in stocks (Luo et al. 2010).

Organic farming practices have also been shown to increase soil C concentrations (Gattinger et al. 2012) which is attributed to the higher rates of $\mathrm{C}$ inputs in organic systems from ley crops and manure/compost inputs. It is therefore possible that merging both farming approaches into organic reduced tillage systems could result in further enhancement of surface soil C concentrations and potentially soil C stocks as well. There have been few studies on organic reduced tillage systems, but Mäder and Berner (2012) showed that the use of reduced tillage in organic farming systems compared to conventional tillage further enhanced soil quality indicators such as organic carbon, microbial activity, and soil structure in the uppermost soil layer. In general, greatest differences were observed when comparing conventional plough treatments (full inversion) with shallow non-inverting cultivation. Enhanced soil microbial activity within organic reduced or no-till systems is particularly important because it can contribute to improved nutrient uptake by arbuscular mycorrhizal fungi (Köhl et al. 2014) and a more efficient cycling of nutrients (Bender and Van Der Heijden 2014). This enhancement of soil biological activity under organic reduced tillage systems may be one strategy to improve crop nutrient supply and ultimately yields, within organic systems.

\section{Material and methods}

Data used in the analysis was sourced from raw field trial data from experiments where tillage intensity was reduced under organic management. In addition, published data from reduced intensity tillage trials in organic systems from both refereed and non-refereed sources was used. In all cases, data was double checked to ensure that raw data used in the analysis was not duplicating published results. Where both raw 
and published results from the same experiment existed, the raw data was used in the analysis.

\subsection{Sourcing and compilation of raw field trial data}

Previously unpublished data from a total of 15 field trials was provided by partners and associates of the TILMAN-ORG project (www.tilman-org.net) (Table 1). Trial managers were provided with a spreadsheet for entering the details of the field trials including site information, experimental design, trial management, and annual results for key response variables. Values for response variables were provided as means for each treatment and information on the number of replications $(\mathrm{N})$ and variability of the mean (standard error or standard deviation) were recorded. Data on crop yields, soil C, and weeds were compiled. Yield data was compiled as marketable yields, or total yields when marketable yield data was not available. Soil $\mathrm{C}$ values were recorded as stocks in $\mathrm{g} \mathrm{m}^{-2}$. Where soil $\mathrm{C}$ was provided as a concentration and bulk densities were available, stocks were calculated by multiplying the $\mathrm{C}$ concentration by the bulk density and sampling depth. If soil $\mathrm{C}$ was only provided as a concentration, stocks were calculated using the pedotransfer function for bulk density reported by Gattinger et al. (2012) and the value was converted to a stock as described above. C stock comparisons between each paired control and experimental treatment were always based on the same sampling depth. Sampling depths ranged from $0-15$ to $0-35 \mathrm{~cm}$. If stocks or concentrations for more than one layer were reported (e.g., $0-15$ and $15-30 \mathrm{~cm}$ ), then the stocks for each layer were calculated and summed to a uniform depth.

Weed data were also compiled. Each study did not use the same measure of weed pressure with three different possible measurement units identified: biomass $\left(\mathrm{g} \mathrm{m}^{-2}\right)$, cover (\%), or density $\left(\# \mathrm{~m}^{-2}\right.$ ). We selected data based on just one of these units from a given experiment, using biomass where available as the best measure of weed pressure, followed by density and cover if biomass data was not available. Initially, weed data were divided into four different plant types: annual monocots, annual dicots, perennial monocots, and perennial dicots. To allow comparison of the weed data across experiments, values for each of the different plant types for a given measurement unit were summed to create a new response variable: weed incidence.

For crop yields and weed data the effect size was calculated as the ratio between the experimental and control treatments. This resulted in an effect size that was standardized and unitless; therefore, it was not necessary to have the same units of measurement when combining data from different experiments. This allowed inclusion of data reported using any of the three weed measurement units used in the experimental studies. For the soil $\mathrm{C}$ data, since all measurements were in the same units $\left(\mathrm{g} \mathrm{m}^{-2}\right)$ the effect size was calculated as the mean difference. This allowed presentation of the effect in actual units of mass per area.

Data from all the experimental years available were included in the dataset.

\subsection{Published data sourcing and selection}

A literature survey of peer-reviewed published literature in the ISI-Web of Science and CAB Abstracts (Ovid) between 1910 and 2013 was conducted to identify papers reporting results from studies using reduced tillage in organic farming. The following search terms and their variations were used in various combinations: reduced/minimum/shallow/chisel, tillage/ploughing/plowing, intensity, no-till/direct seeding, organic/ecological, farming/systems/agriculture/management. The initial search provided around 180 papers published from 1986 to 2013 in scientific journals from the Web of Science. More relevant papers were found by searching through the reference lists of papers already selected for the meta-analysis and recommendations of experts in tillage research. We also extracted data from non-peer reviewed sources for the analysis. Field trials that were possibly relevant for the metaanalysis were found via webpages (http://www.orgprints. org/) dedicated to research in organic agriculture as well as recommendations of tillage researchers. These sources were provided by the study authors who submitted theses and reports, often in their native language, for inclusion in the analysis.

All studies were scrutinized and only included if they met the following selection criteria: (i) experiment under organic management for at least 3 years prior to the date of response measurement; (ii) at least two levels of tillage intensity included as a treatment; (iii) no "mixing" of treatments, i.e., only tillage varied between experimental treatments; and (iv) included climatic zones found in Europe (Table 2). This screening process resulted in 26 published studies being identified ( 20 peer reviewed and 6 non-peer reviewed; see Table 1).

Details on the field trials identified from published sources, and the values of the response variables were entered into the same database used to compile the raw data from trials as explained in Sect. 3.1.

\subsection{Characterization of the data}

We assigned the tillage treatment factor in each experiment to a class based on the level of tillage intensity. The six tillage classes in order of decreasing intensity were as follows: deep inversion (greater than or equal to $25 \mathrm{~cm}$ depth), double-layer ploughing (inversion of the soil to a depth of $\sim 15 \mathrm{~cm}$ and loosening to $\sim 30 \mathrm{~cm}$ (Gruber and Claupein 2009; Vakali et al. 2011), shallow 


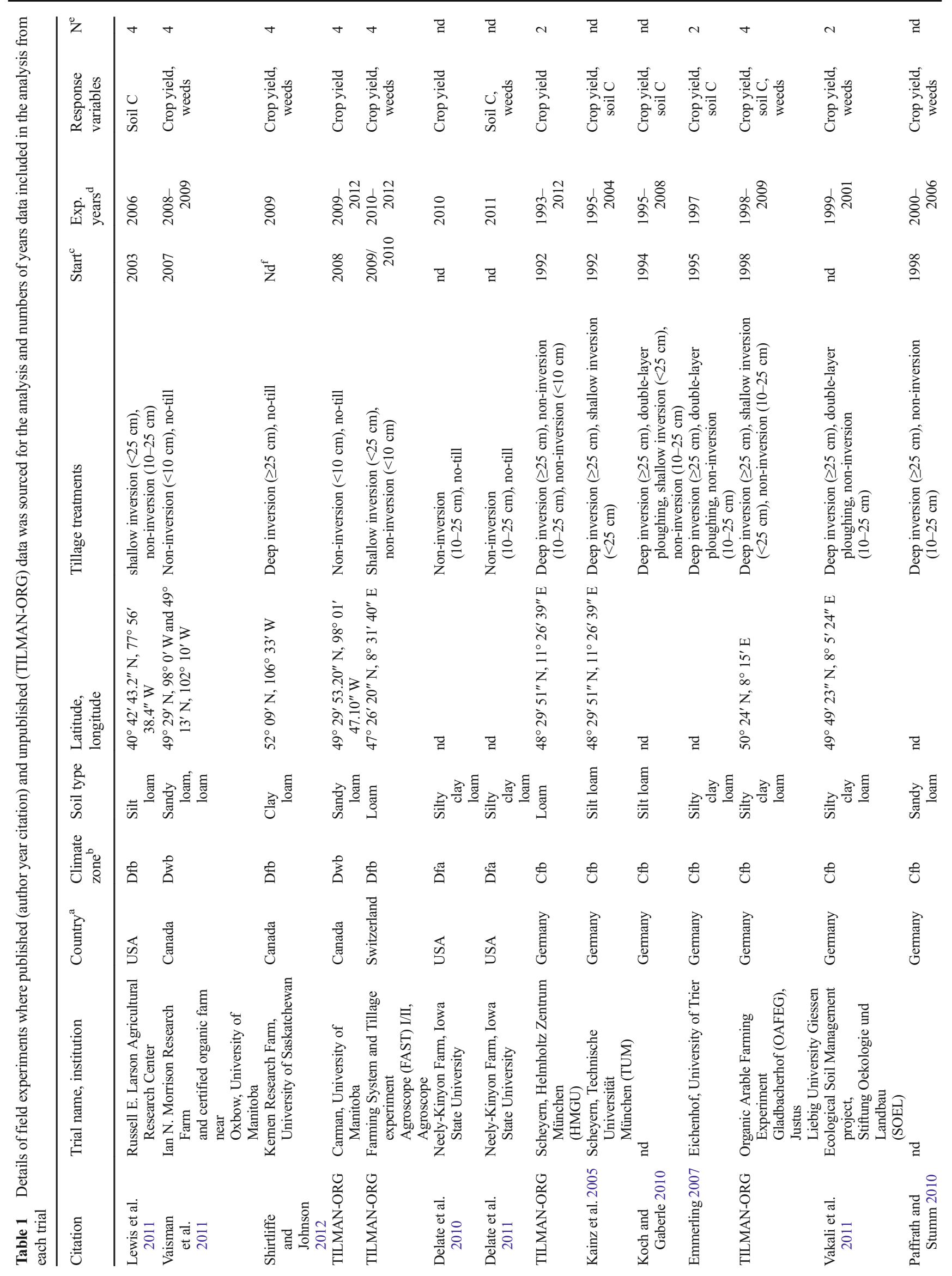




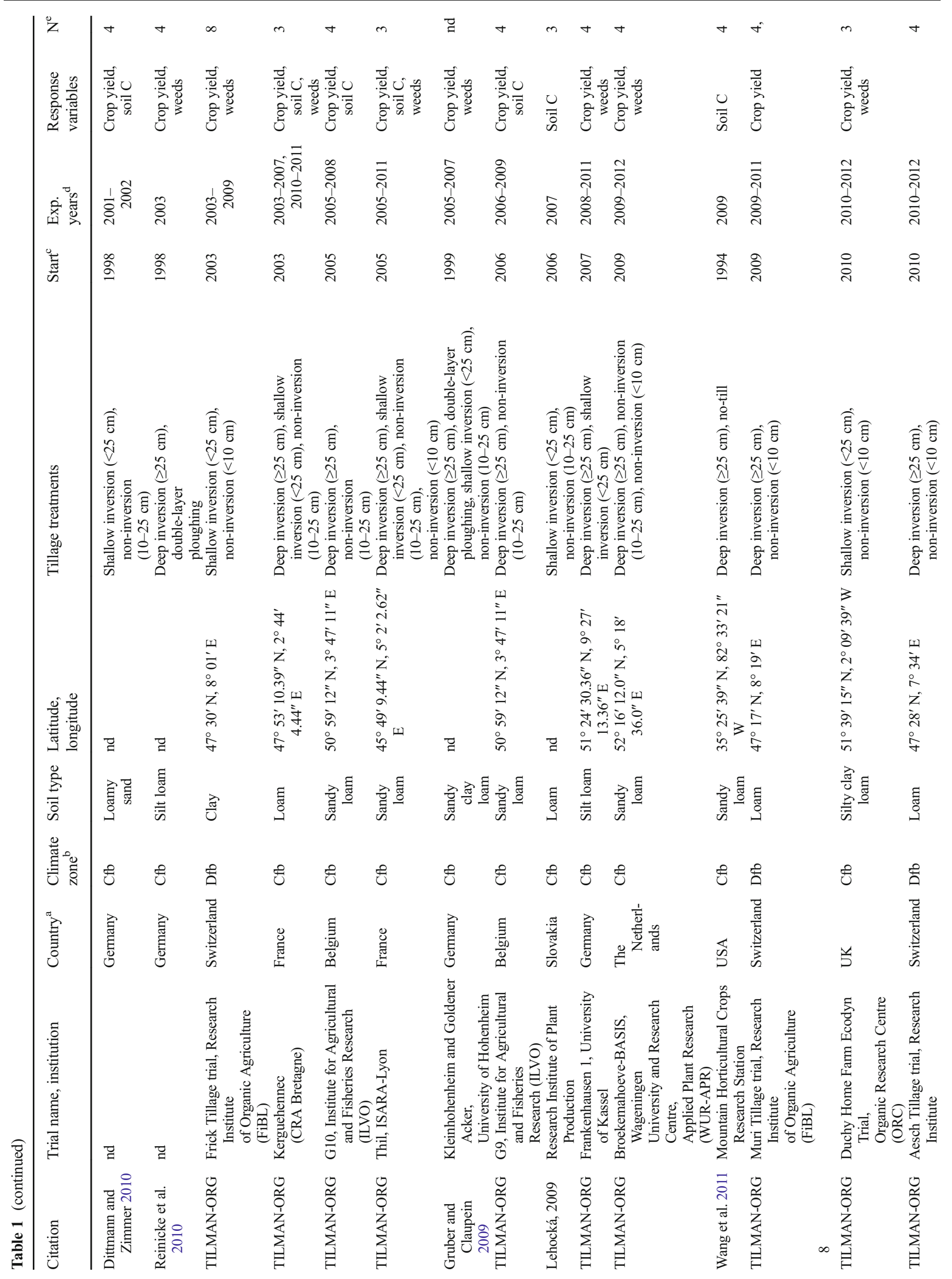




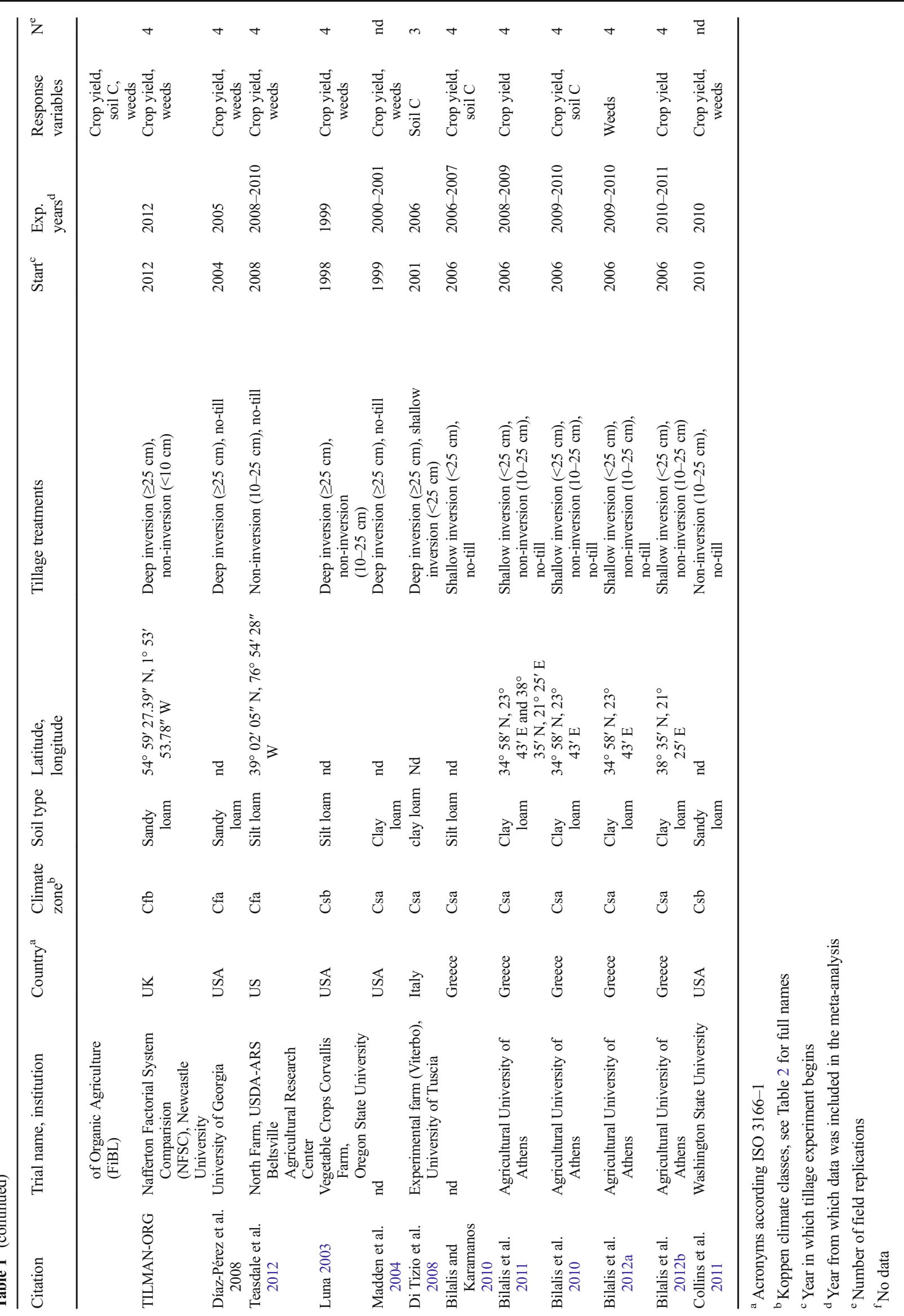


inversion (less than $25 \mathrm{~cm}$ depth), non-inversion (10-25 $\mathrm{cm}$ depth), non-inversion (less than $10 \mathrm{~cm}$ depth), and notill (Fig. 2). We also collected information from the field trials and selected published data to further describe the environmental and management factors for each study. Environmental variables included as factors were soil type and climate defined in nine climatic zones as described in Quemada et al. (2013) (Table 2). Soil types were grouped into three categories according to USDA texture classes (Soil Survey Division Staff 1993): heavy, which included all soils with a clay content greater than $40 \%$ (sandy clay, silty clay, clay); light, which included all soils with less than $40 \%$ clay and greater than $50 \%$ sand (sand, loamy sand, sandy loam, sandy clay loam); and loamy, which included all other soils (silt, silty loam, medium loam, clay loam, silty clay loam). Management factors included in the analysis were crop rotation class, mechanical weeding class, and main crop and previous crop class (Table 2). Crop rotations were assigned to

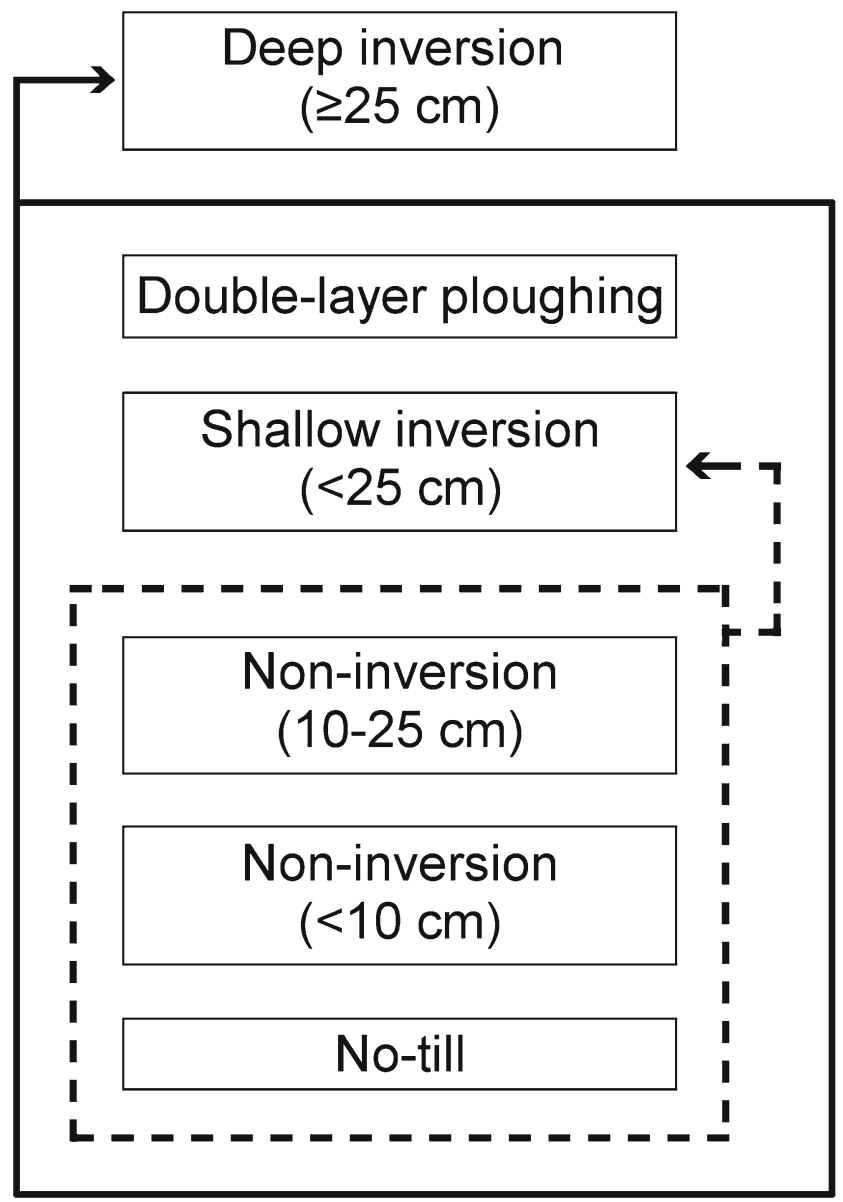

Fig. 2 Hierarchy of tillage intensities used to classify experimental treatments. Treatments within the box outlined in a solid line were part of the first set; the connecting arrow indicates the control treatment for this set. Treatments within the box outlined in a dashed line were part of the second set; the connecting dashed arrow indicates the control treatment for this set one of four types: intensive arable (i.e., no ley crops); arable with ley periods; intensive horticulture (i.e., no ley crops); horticulture with ley periods. For the purposes of this study, we defined a ley period as a full season of a soil building crop such as grass/clover. Crops grown for soil building purposes for less than a year were considered green manures. Main crops and previous crops were divided into three classes: combinable crops (e.g., winter and spring grains, maize, legumes); non-combinable crops (e.g., leaf vegetables and root vegetables including potatoes); cover crops/leys (as described above).

\subsection{Data analysis}

Many of the published studies did not provide an estimate of variance which meant it was not possible to use a weighted meta-analysis approach for this analysis; therefore, results for unweighted analyses only are presented in this paper. Data were analyzed using unweighted meta-analysis techniques in the R statistical software package (www.r-project.org; R Development Core Team 2011). An observation pair consisted of a data point for a designated control treatment and a data point for an experimental treatment, for each experimental year, crop, and fertilization management. Two preliminary subsets of data were identified. The first set included all experiments with deep inversion tillage (greater than or equal to $25 \mathrm{~cm}$ depth) as a treatment. For this set, deep inversion tillage was designated as the control treatment and all other treatments were compared with this control. A second set of data included all experiments with shallow inversion tillage (less than $25 \mathrm{~cm}$; as shown in Armengot et al. 2015 Fig. 1b) as a treatment but without a deep inversion treatment. For the second set, shallow inversion tillage was designated as the control treatment and all other treatments were compared with this control. Double-layer ploughing was classified as intermediate in intensity between deep inversion and shallow inversion. Only five experiments included double-layer ploughing as a treatment, and these were all part of the first set of data that also included deep inversion as a control. It should be noted that 5 out of the 41 experiments were included in both sets of data, if they included deep inversion and shallow inversion, as well as other tillage treatments. This was the case for the OAFEG (Giessen, Germany), Kerguehennec (Bretagne, France), and Thil (ISARA, France) trials as well as for experiments in Germany reported by Koch and Gaberle (2010) and Gruber and Claupein (2009).

The effect size for each yield and weed incidence observation pair was calculated as the response ratio $(r=X e / X c)$, where $X e$ is the experimental treatment mean and $X c$ is the control mean of each variable. For the soil $\mathrm{C}$ data, since all measurements were in the same units $\left(\mathrm{g} \mathrm{m}^{-2}\right)$, the effect size was calculated as the mean difference $(\mathrm{MD}=X e-X c)$. 
Table 2 Environmental and crop management factors and classes within each factor for the raw trial data and selected published data

\begin{tabular}{|c|c|}
\hline Factor & Classes \\
\hline Soil type (USDA texture class) & $\begin{array}{l}\text { Clay, clay loam, loam, loamy sand, sandy clay loam, sandy } \\
\text { loam, silt loam, silty clay loamb }\end{array}$ \\
\hline European climate zone (Koppen climate class) & $\begin{array}{l}\text { Mediterranean (Csa, Csb), humid subtropical (Cwa, Cwb, Cfa), } \\
\text { humid oceanic (Cfb), humid continental (Dfa, Dfb, Dwb) }\end{array}$ \\
\hline Crop rotation class & $\begin{array}{l}\text { Arable with ley periods, intensive arable (no ley crops), } \\
\text { intensive horticulture (no ley crops) }\end{array}$ \\
\hline Mechanical weeding (per growing season) & None, once, $2-4$ times, 5 or more times \\
\hline \multicolumn{2}{|l|}{ Crop/previous crop classes } \\
\hline $\begin{array}{l}\text { Legume or grass/legume mixture grown for } \\
>12 \text { months }\end{array}$ & Legume ley \\
\hline $\begin{array}{l}<12 \text { months legume cover crop primarily for } \\
\text { soil protection/improvement }\end{array}$ & Legume cover crop \\
\hline $\begin{array}{l}<12 \text { months cover crop primarily for soil } \\
\text { protection/improvement }\end{array}$ & Non-legume cover crop \\
\hline $\begin{array}{l}\text { Annual cash crop of vegetable where above } \\
\text { ground parts are marketed }\end{array}$ & Leaf vegetable \\
\hline $\begin{array}{l}\text { Annual cash crop of vegetable where below } \\
\text { ground parts are marketed }\end{array}$ & Root vegetable \\
\hline $\begin{array}{l}\text { Barley, wheat, rye, oats, spelt sown in the } \\
\text { autumn }\end{array}$ & Winter small-grain cereal/oilseed \\
\hline $\begin{array}{l}\text { Barley, wheat, rye, oats, spelt sown in the spring } \\
\text { or summer }\end{array}$ & Spring small-grain cereal/oilseed \\
\hline Annual cash crop of legume & Peas/beans \\
\hline Grain or silage maize or sorghum & Maize/sorghum \\
\hline
\end{tabular}

${ }^{\text {a }}$ As used in Quemada et al. (2013)

${ }^{\mathrm{b}}$ As described in Soil Survey Division Staff (1993)
The outliers among response ratios were rejected using a robust statistical method in which a "Tukey fence" was established and all values outside the interquartile range were considered as outliers (Hoaglin et al. 2000). The range was calculated from $Q_{1}-k \times I Q R$ to $Q_{3}+k \times I Q R$, where $Q_{1}$ is the lower quartile point, $Q_{3}$ is upper quartile point, IQR is the interquartile range $\left(Q_{3}-Q_{1}\right)$, and $k$ is a non-negative constant (here 1.5).

The significance of effect sizes was tested using linear mixed effects models in the "Ime4" package in R with random effects specified as experiment/year. The fixed effects of tillage class or climate were tested using this model. The effect of tillage class within a given soil type or crop class was tested after first subsetting the data by soil type or crop class and then using a mixed effects model as described above. For all analyses, leastsquare means and confidence intervals were generated using the "Ismeans" package in R. Means were considered significantly different from zero if the $95 \%$ CI did not overlap zero, and different from one another if their $95 \%$ CIs were nonoverlapping (Hedges et al. 1999). The results of each mean ratio $(r)$ were expressed as \% effect size $(e)$, where $e=(r-1) \times 100$.

To investigate the relationship between weed incidence and crop yields, we modeled the relationship between crop yield response ratio and weed response ratio using linear regression in the "ggplot2" package in R. This fits a straight line through the set of $n$ points to minimize the sum of squared residuals of the model (that is, vertical distances between the points of the data set and the fitted line).

\section{Results and discussion}

\subsection{Crop yield effects of reduced tillage intensity in organic systems}

We found that on average across all environments and management practices yields were $7.6 \%$ lower when tillage intensity was reduced in organic systems compared to deep inversion tillage (total 873 observation pairs from 21 studies; Fig. 3a). This is greater than the $2.8 \%$ average yield reduction reported for conventional reduced tillage systems in Europe (Van den Putte et al. 2010). We expected to see yield reductions from reduced tillage in organic systems, as reported by Mäder and Berner (2012) in their review of European research; however, the effects were not obviously related to our classification of tillage intensity. When we considered the various classes of reduced tillage compared to deep inversion (Fig. 3a), we found that the reductions in yield for both double-layer ploughing (7\%) and shallow inversion tillage (5.5\%) were relatively small and for shallow non-inversion tillage the reduction of $3 \%$ was non-significant. Although the tillage methods in Fig. 3a are 
Fig. 3 Overall effect on crop yields of reduced tillage and effect of each tillage method relative to a deep inversion tillage and $\mathbf{b}$ shallow inversion tillage. Mean values and $95 \%$ confidence intervals of the back-transformed response ratios are shown. Sample sizes (i.e., the number of control-treatment pairs)/number of experiments are shown on the right of the confidence intervals
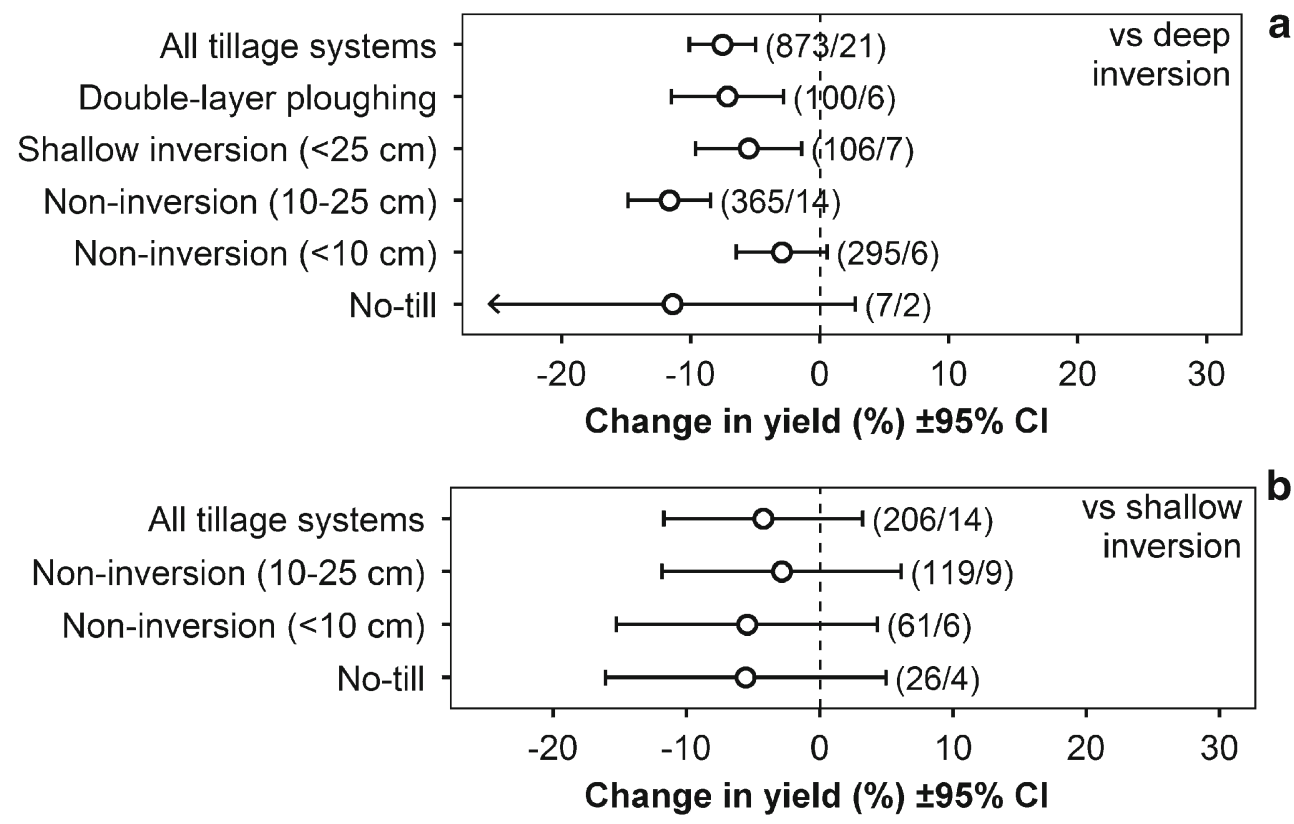

arranged in order of declining intensity from top (double-layer) to bottom (no-till), there is no clear trend of increasing yield reductions with reductions in tillage intensity. Surprisingly, deeper non-inversion tillage $(10-25 \mathrm{~cm})$ resulted in a significantly greater reduction in yield $(11.6 \%)$ relative to deep inversion tillage than shallow non-inversion (less than $10 \mathrm{~cm}$ ) which did not significantly reduce yield. This contradicts the results of the meta-regression carried out by Van den Putte et al. (2010) who concluded that yields were higher when tillage depth was increased in non-inversion systems. Soil type may be influencing the results in our study. Closer inspection of the dataset indicated that the six studies included in the shallow non-inversion set represented only soils with loam or sandy loam textures. The deep non-inversion set included soils with a higher clay content, e.g., sandy clay loam, silty clay loam, and silt loam soils, as well as loam and sandy loam. Arvidsson et al. (2013) carried out a detailed study on the impacts of tillage depth in non-inversion systems in Sweden and found a slight negative correlation between crop yield and clay content. This was attributed to changes in soil structure at depth in deep non-inversion tillage systems, which disturbed transport of water and nutrients. In our study, this impact may also account for the large yield reductions for deep non-inversion tillage relative to shallow non-inversion.

For the second subset of data where shallow inversion tillage was the control treatment, yields on average were $4.2 \%$ lower when tillage intensity was reduced, but this difference was not significant (total 206 observation pairs from 14 studies; Fig. 3b). In spite of the relatively large number of observation pairs and studies included, confidence intervals for this subset were still large and do not allow any firm conclusions to be drawn.

\subsection{Influence of climate and soil type on yields in organic reduced intensity tillage systems}

It has been suggested that the success of reduced intensity tillage systems in organic farming is largely dependent on local environmental conditions, including climate and soil type (Vian et al. 2009; Krauss et al. 2010). To investigate this, we conducted separate analyses of yield effects for each climate and soil class.

Figure 4a shows the overall effect of each climate class when tillage intensity is reduced relative to deep inversion. The dataset was primarily comprised of experiments from the humid continental zone; therefore, the yield reduction for this climate class $(8 \%)$ is similar to the yield reduction for the whole dataset. For the three studies that were conducted in the humid oceanic climate there is a less than one percent reduction in yield, while results from the Mediterranean zone show large yield reductions, although these represent only two studies (Luna 2003 and Madden et al. 2004) so should not be considered as broadly representative of tillage effects on yields in this climate zone.

As noted in the first analysis, there are no significant effects of reduced tillage intensity in the subset of data where shallow inversion tillage is used as the control (Fig. 4b). The trend toward increases in yield in the Mediterranean climate zone is interesting and deserves further investigation. In these regions, reducing tillage intensity may increase the amount of crop residues on the soil surface which improves soil and water conservation and enhances crop yields (Soane et al. 2012). This is a benefit frequently ascribed to conservation agriculture systems under conventional management, and it is reasonable to assume that improvements in soil water relations under organic 
Fig. 4 Overall effect of reduced tillage and effect of each climate class on yields relative to a deep inversion tillage and $\mathbf{b}$ shallow inversion tillage. Mean values and $95 \%$ confidence intervals of the back-transformed response ratios are shown. Sample sizes (i.e., the number of control-treatment pairs)/number of experiments are shown on the right of the confidence intervals
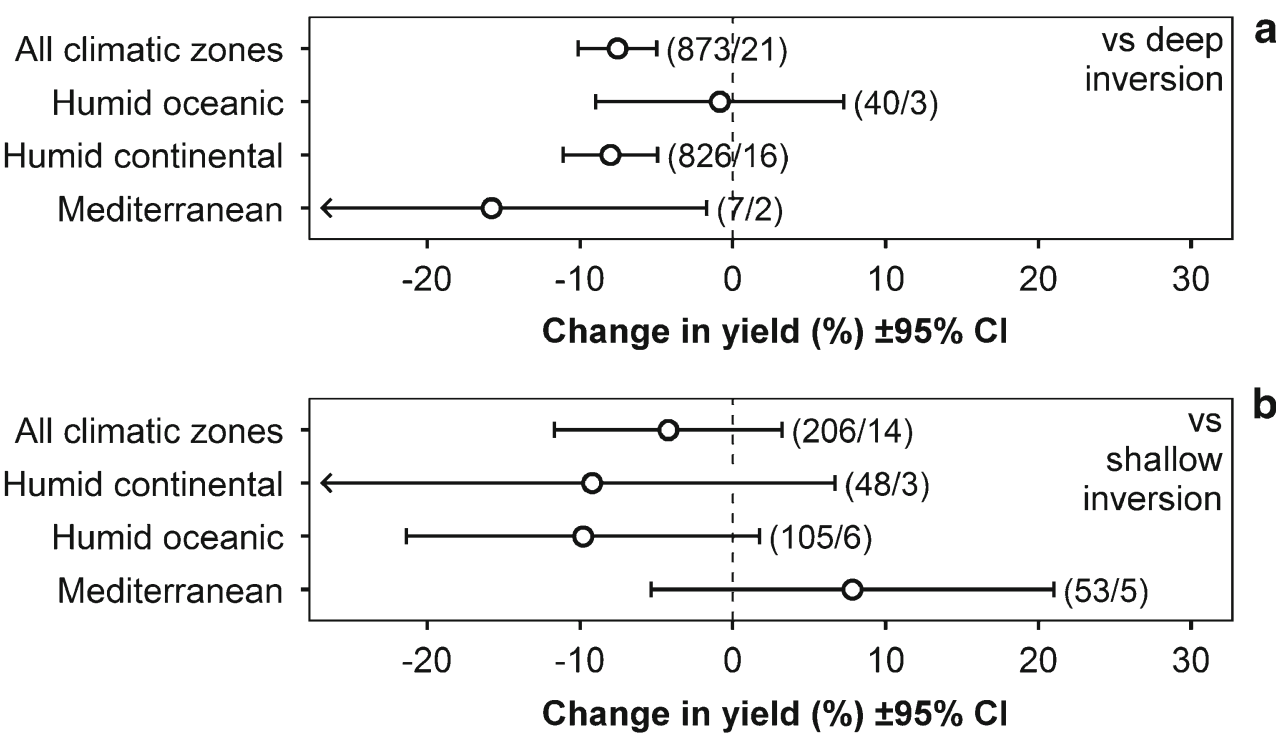

management also occur. Further experiments on reduced tillage intensity in organic systems in the Mediterranean are needed to allow a more robust meta-analysis of the factors influencing crop yield in organic reduced tillage systems in this environment.

The impact of soil type on yields where tillage intensity was reduced relative to deep inversion was similar for the loamy soil group ( $-8 \%$; Fig. 5a) and the light soil group ( $-6 \%$; Fig. $5 b)$. For the loamy soils, in this subset of data, there was some variation in the yield effect depending on the tillage class: doublelayer ploughing, shallow inversion, and deep non-inversion tillage all significantly reduced yield, while the shallow noninversion class of tillage did not result in any yield reduction.
On the light soils, there was a trend toward yield reductions when either depth of non-inversion tillage was used. Van den Putte et al. (2010) also found the greatest yield reductions in no-till and reduced tillage systems on sandy soils. This may at first seem counterintuitive, but it is related to the challenge of building good soil structure in light, sandy soils. These soils lack the fine particles necessary to form the organo-mineral complexes that are the building blocks of soil aggregates (Bronick and Lal 2005), and are not de-compacted naturally by the climate since they have no shrinkage and swelling effects. Earthworm populations are also significantly lower in soils with a sandy texture (Lapied et al. 2009), so they lack these "ecosystem engineers" to build soil structure. These
Fig. 5 Overall effect of reduced tillage and effect of each tillage method on yields relative to deep inversion for a loam and $\mathbf{b}$ light soil types. Mean values and $95 \%$ confidence intervals of the backtransformed response ratios are shown. Sample sizes (i.e., the number of control-treatment pairs)/number of experiments are shown on the right of the confidence intervals
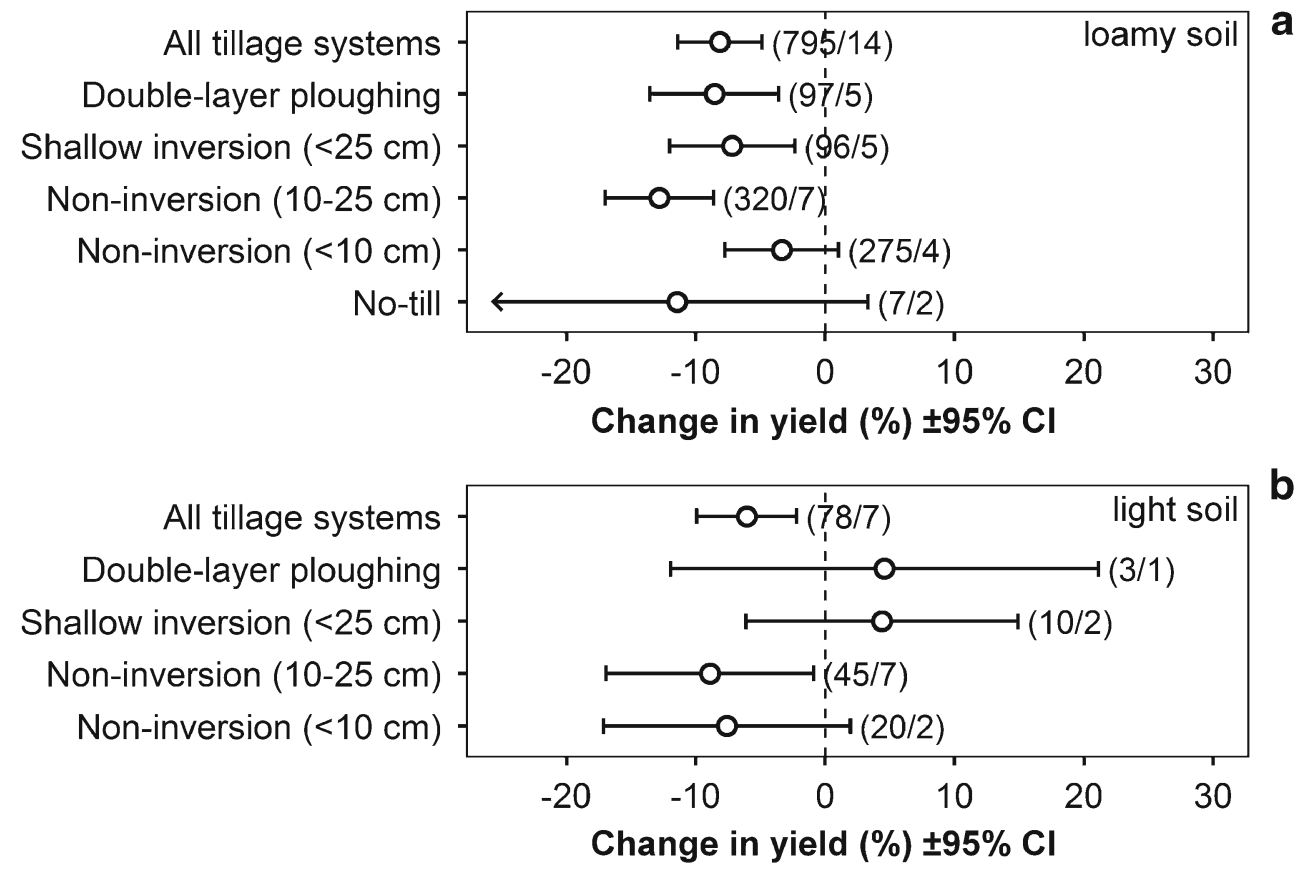
factors mean that without regular tillage, light soils can slump and become compacted compared to loamy or clayey soils.

Relative to shallow inversion, there was a significant reduction in yields for the 14 observation pairs from the two experiments conducted on the light soils (17\%), but no reduction for the loamy soil group (data not shown). There was only one study in the analysis that was conducted on heavy soils; for this case, yields were higher by $10 \%$ when shallow noninversion tillage was used rather than shallow inversion tillage. This supports the findings from the first dataset showing that lighter soils tend to exhibit higher yield reductions than heavy soils, as reported in Van den Putte et al. (2010).

\subsection{Impact of crop choice and rotational sequence on success of reduced tillage intensity in organic systems}

The actual crop grown had some effect on the yield reduction relative to deep inversion tillage (Fig. 6) but no effect for the subset where shallow inversion tillage was the control (results not shown). Combinable crops such as wheat and maize suffered the greatest average yield reductions (Fig. 6a; $8 \%$ ), and this was particularly pronounced when deep non-inversion tillage was used when yield reductions were $13.5 \%$. This reflects the results of a Swedish study in conventional systems where the authors compiled results for 918 experimental years and found significantly lower yields for winter wheat in shallow tillage systems as well as lower yields for sugar beet (Arvidsson et al. 2014). They concluded that for cereals, yields may be limited by the residues of the previous crop which could result in difficulties with crop establishment and increased disease pressure. In organic systems where fungicides are not permitted, control of cereal fungal diseases is usually achieved by crop rotation and incorporation of residues into the soil (Lampkin and Measures 2001). Without the option of incorporating residues, disease pressure in organic reduced tillage systems may be higher than conventional systems and contribute to the lower yields found in our study.

Yield reductions for non-combinable crops were $6 \%$ (Fig. 6b). The majority of the non-combinable crops included in the study were root crops, either potatoes or carrots. A closer investigation of tillage practices for these root crops indicates that while depth of tillage may be shallower at the primary tillage stage, in many cases (e.g., Scheyern trial), there are several subsequent tillage operations performed including rototilling prior to planting and ridging as many as three times during crop growth. These practices could result in soil conditions not unlike those in the control plots and also reduced weed incidence, both of which could explain why root crops do not experience as large a yield reduction as the combinable crop category.
Fig. 6 Overall effect of reduced tillage and effect of each tillage method on yields relative to deep inversion for a combinable, $\mathbf{b}$ non-combinable, $\mathbf{c}$ cover crops/ leys crop types. Mean values and $95 \%$ confidence intervals of the back-transformed response ratios are shown. Sample sizes (i.e., the number of control-treatment pairs)/number of experiments are shown on the right of the confidence intervals
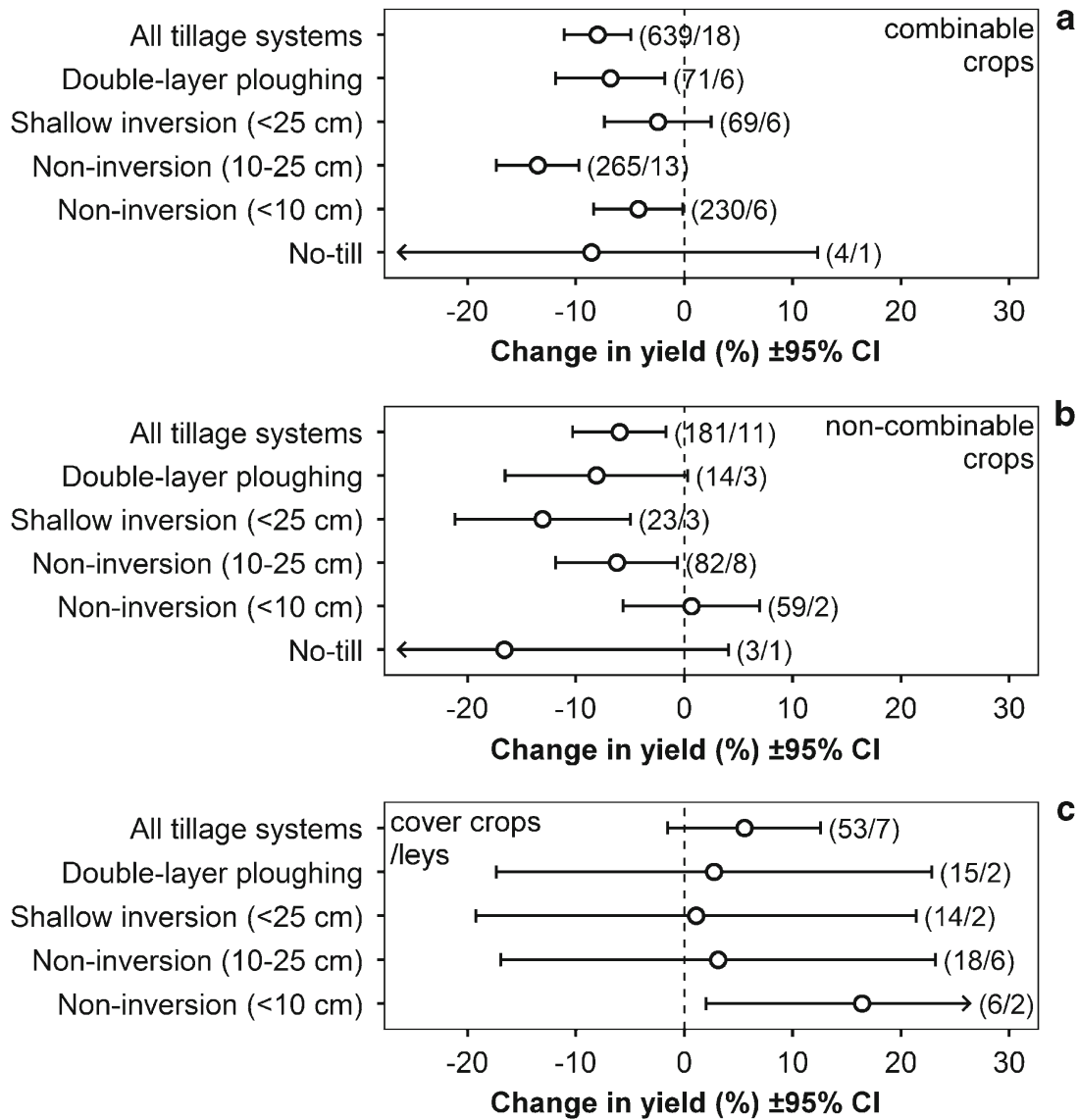

C 
In general, cover crops and leys were not affected by reductions in tillage intensity (Fig. 6c). There is some evidence that reducing tillage intensity can benefit ley crops. For instance, grass-clover leys in reduced tillage plots of the Frick tillage trial profited in drought periods from better capillary water supply from the ground, and produced more yield (Krauss et al. 2010). This was remarkable, as the establishment method for the ley in both the plough and the reduced tillage systems in the Frick trial was the same, indicating a lasting effect of tillage treatments prior to ley establishment.

In most cases, the choice of previous crop (data not shown) did not alter the effect on subsequent crop yields; a previous combinable crop or cover crop/ley resulted in similar average yield reductions of $\sim 7-8 \%$ relative to deep inversion. This does not confirm the widely held belief among organic farmers that the mouldboard plough is essential for incorporation of ley crops. Without the option of killing off a grass/ legume cover with a herbicide, as commonly practiced among the non-organic no-till community, many organic farmers rely on deep inversion tillage to destroy the ley crop and minimize the risk of grass becoming a weed in subsequent crops (Lampkin and Measures 2001). In practice, this may not be necessary or organic farmers may want to develop a "hybrid" system of tillage where some inversion tillage is still used at specific stages of the rotation (e.g., for incorporation of a ley or for burying cereal residues for disease control) while other reduced tillage options are implemented following some combinable or non-combinable crops. Carr et al. (2013) describe an organic zero till (ZT) system where soil is left undisturbed during certain phases of the rotation, and strategically tilled at other phases, primarily to suppress weeds.

\subsection{Impact of time under reduced tillage on crop yields in organic systems}

There is a common perception that yield reductions following the adoption of reduced tillage will be ameliorated over time (Soane et al. 2012). This has been attributed to various factors including short-term problems with soil compaction before soil structure has improved, reduced $\mathrm{N}$ availability in the short term, and operators initially lacking practical experience (Soane et al. 2012). To find out if this was the case in organic systems, we plotted the effect size (\% change from the control) versus the number of years that the tillage treatment had been implemented (Fig. 7). For both cases, there was no clear trend toward a smaller yield effect over time. We did not have
Fig. 7 Effect of length of treatment period on yield in units of percent change from the control yields: a control $=$ deep inversion tillage and $\mathbf{b}$ control $=$ shallow inversion tillage. Mean values and $95 \%$ confidence intervals of the backtransformed response ratios are shown (open circles). Sample sizes (i.e., the number of controltreatment pairs)/number of experiments are shown above each mean. Dots represent each observation pair

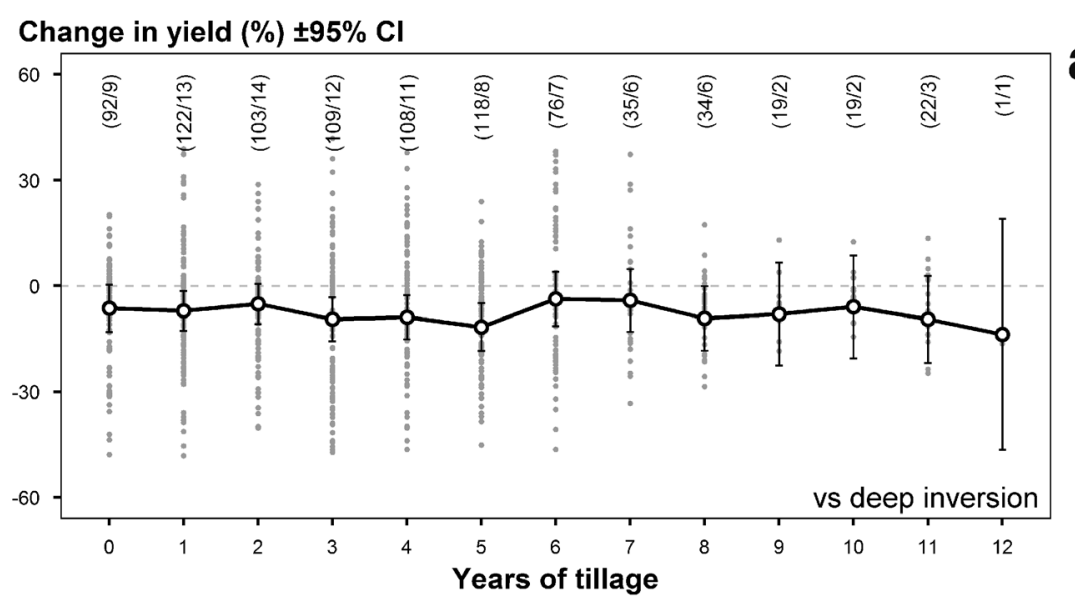

Change in yield $(\%) \pm 95 \% \mathrm{Cl}$

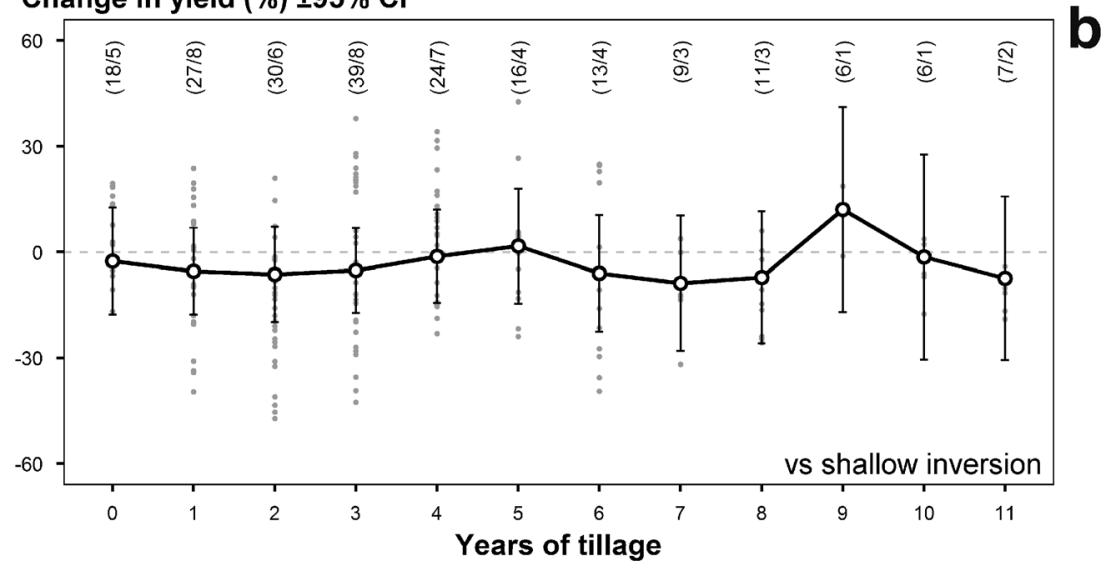


enough observation pairs to investigate the interaction between crop rotation and length of time that reduced tillage had been implemented; however, Van den Putte et al. (2010) found that for cereal only rotations the relative yield gradually declined due to the buildup of pests and diseases. This may also be happening in our studies. Although organic rotations are usually characterized by a high degree of diversity and ley periods for prevention of weeds and disease and the regeneration of soil fertility (Lampkin and Measures 2001), in the first dataset (using deep inversion tillage as a control) about $20 \%$ of the observation pairs came from studies classified as "intensive arable" with no ley periods in the rotation. The second subset of data represented an even higher proportion of intensive arable experiments with more than twice falling into this category.

\subsection{Are weeds higher under reduced tillage intensity in organic systems?}

Relative to both deep and shallow inversion tillage, reducing tillage intensity in organic systems increases weed incidence. This is shown in Fig. 8a where deep inversion tillage was used as the control and 94 observation pairs were identified. For this set of data, the overall average increase in weed incidence was $54 \%$ with only shallow inversion and no-tillage showing no increase in weed incidence relative to the control; however, the number of observation pairs for no-till is very low leading to a high degree of uncertainty in the estimate of effect size. Results were similar where shallow inversion tillage was the control and 68 observation pairs were identified (Fig. 8b); here, the overall increase in weed incidence was $56 \%$, with no difference in weed incidence among the tillage classes.
There is a long-standing assumption in the organic production sector that weed pressure will increase if tillage is reduced, and that this will lead to reductions in crop yields (Mäder and Berner 2012). To check if this was the case in our study dataset, we plotted the relationship between the mean effect size for yield and the mean effect size for weed incidence (Fig. 9). A negative correlation between the two parameters would imply that lower yields were associated with higher weed incidence. This was the case when tillage intensity was reduced relative to deep inversion for doublelayer ploughing $(P=0.049)$ and shallow inversion (less than $25 \mathrm{~cm})(P=0.023)$, but not for non-inversion at either depth. This is interesting because the treatment with the greatest yield reduction was deep non-inversion tillage (Fig 3a), yet the relationship between weed incidence and yield was not significant for this tillage class. In the second set of data (shallow inversion tillage control), there was a negative correlation between weed incidence and yields only when deep noninversion was adopted. However, for shallow non-inversion, this relationship was non-significant. These results suggest that while weed incidence may be a factor contributing to yield reductions under reduced tillage, other factors may also be involved.

Since many of our experiments had been running for a relatively short time (see Fig. 7), nutrient supply patterns and soil structural conditions may have had more of an impact on yields than weeds. Yields may be restricted due to delays or limitations in nutrient supply as has been reported when reduced tillage is implemented in conventional systems (Soane et al. 2012). This may create even more of a challenge in organic farming where no supplemental mineral fertilizer inputs are allowed. Soil structural limitations, i.e., compaction in
Fig. 8 Overall effect on weed incidence of reduced tillage and effect of each tillage method relative to a deep inversion tillage and $\mathbf{b}$ shallow inversion tillage. Mean values and $95 \%$ confidence intervals of the back-transformed response ratios are shown.

Sample sizes (i.e., the number of control-treatment pairs)/number of experiments are shown on the right of the confidence intervals
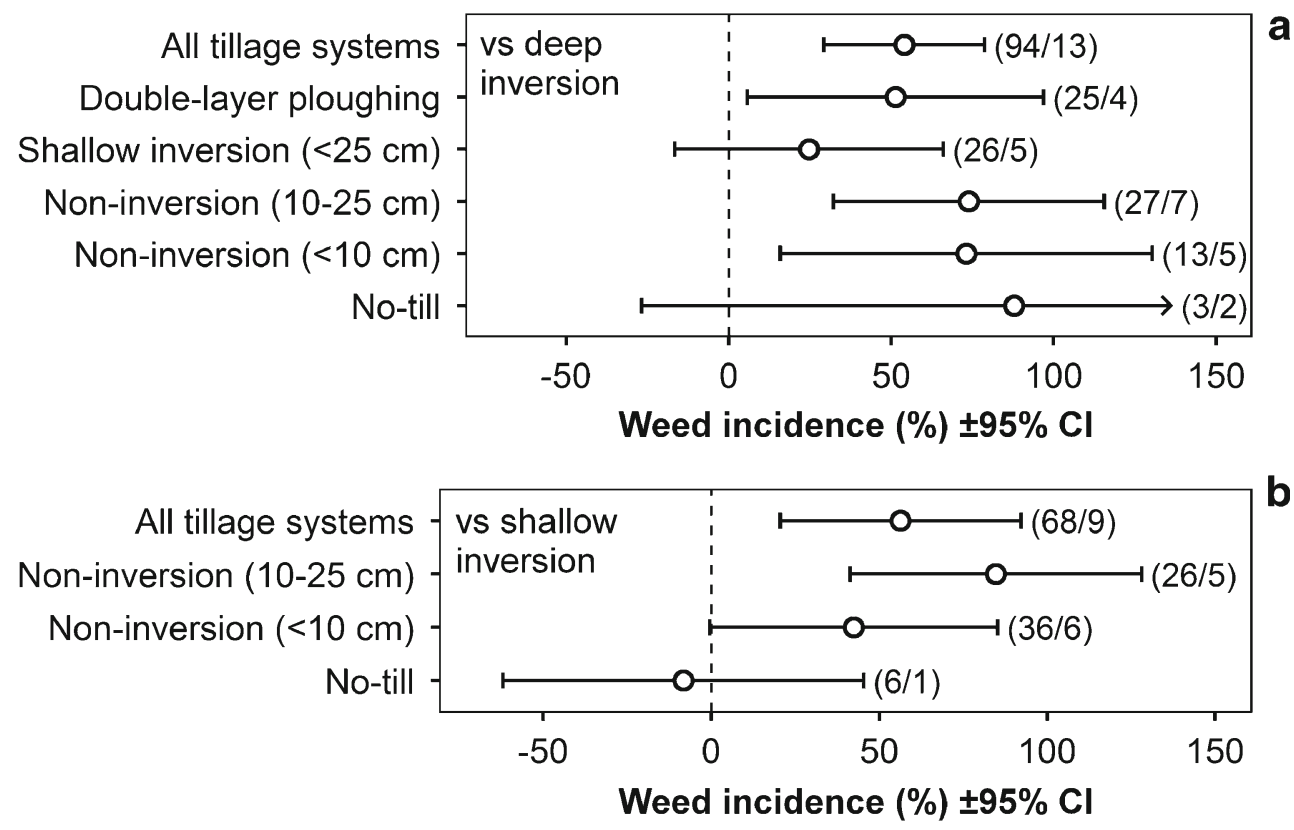
Fig. 9 Relationship between the mean effect size for yield and the mean effect size for weed incidence relative to a deep inversion tillage and $\mathbf{b}$ shallow inversion tillage. Slopes were significant for a double-layer ploughing $(P=0.049)$; shallow inversion tillage $(P=0.023)$ and $\mathbf{b}$ non-inversion tillage $(P=0.030)$

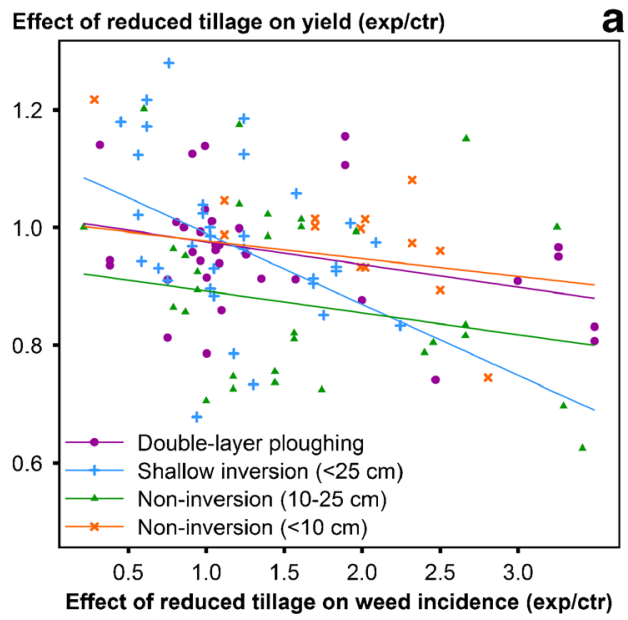

a

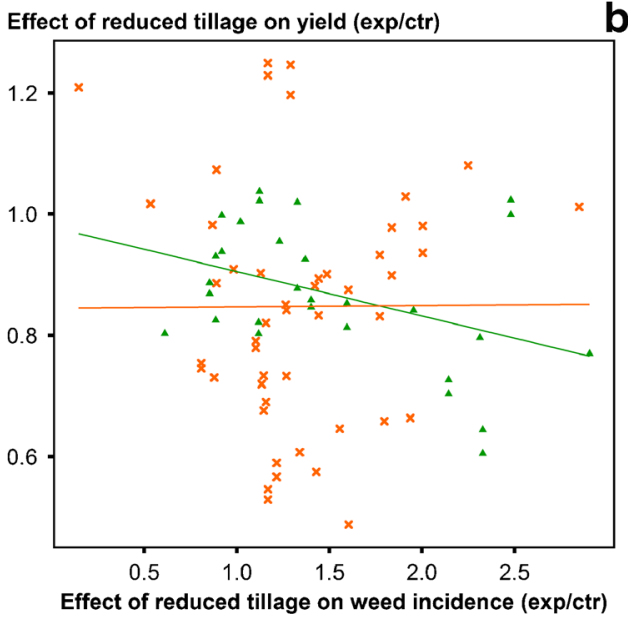

the short term, may also create suboptimal conditions for root growth (Soane et al. 2012). Typically, these problems are more prevalent in reduced tillage systems during the initial "transition" period.

In contrast, weed populations may build up over time once reduced tillage is implemented (Armengot et al. 2015). In the first years after transition to reduced tillage, the weeds may not have reached the critical threshold level where they start to restrict yields (Peigné, personal communication). Nevertheless, our study showed a clear trend toward higher weed incidence when tillage intensity was reduced (see Fig. 8). Since organic farmers have few options to control weeds once they become a problem, this trend is of particular concern in a system where tillage is not available as a weed control method. In organic reduced tillage systems, farmers will have to be extra vigilant to ensure that weeds do not become a problem and employ creative approaches including cover crops, diverse rotations, timely mowing of problem weeds, and integration of smother and/or allelopathic crops to manage weed populations (Anderson 2015; Jabran et al. 2015).

\subsection{Impacts of reduced tillage intensity in organic systems on soil C stocks}

A preliminary analysis of the data for both subsets of data where soil C stocks were reported or calculated was conducted to test if the sampling depth $(0-20,0-25,0-30 \mathrm{~cm}$ and not reported) had any effect on the size of the standard mean difference (results not shown). This showed that sampling depth did not affect the size of the standard mean difference demonstrating that it was valid to pool results from studies which measured stocks at different depths (although the same sampling depth was used for any given observation pair).

There were a total of 184 observation pairs in the first dataset where reduced tillage intensity was compared to deep inversion tillage. For this set of data, all reductions in tillage intensity increased soil $\mathrm{C}$ stocks by $143 \mathrm{~g} \mathrm{~m}^{-2}$ (Fig. 10a). There was little difference in the relative increase in $\mathrm{C}$ stocks depending on the tillage class, although shallow non-inversion (less than $10 \mathrm{~cm}$ ) did not result in a significant increase in $\mathrm{C}$ stocks relative to the deep inversion control. For the second subset of data where reduced tillage intensity was compared to shallow inversion tillage, there was no clear increase in soil C stocks when tillage intensity was reduced (Fig. 10b).

Gattinger et al. (2012) have already demonstrated that organic farming practices can result in enhanced soil $\mathrm{C}$ stocks. On average, they report $\mathrm{C}$ stocks that are $198 \mathrm{~g} \mathrm{C} \mathrm{m}^{-2}$ higher in organic systems compared with conventional in the top $15 \mathrm{~cm}$. These gains were attributed to the higher rates of $\mathrm{C}$ inputs in organic systems from ley crops and manure/compost inputs. Tillage practices were not considered in their study; therefore, these gains occurred over a range of tillage methods with mouldboard ploughing assumed to be the most common practice. Our study demonstrates that further gains in soil C stocks in the topsoil can be achieved in organic farming systems by reducing tillage intensity in mouldboard ploughbased systems, something that has also been shown in numerous studies in conventional systems (West and Post 2002). This increase in topsoil stocks, which results from higher $\mathrm{C}$ concentrations in topsoil, can result in improved soil physical and biological quality, one of the key benefits of reduced tillage systems (Angers and Eriksen-Hamel 2008). Higher C concentrations result in a range of soil quality and ecosystem service benefits including higher water infiltration rates, improved aggregate stability, reduced erosion risk, enhanced soil biological activity, and improved soil nutrient cycling (Fließbach et al. 2007).

However, gains in topsoil stocks of organic $\mathrm{C}$ in systems with reduced tillage intensity do not always translate into net gains in stocks if deeper sampling depths are included (see Sect. 2.3). This is why scientists are increasingly cautious about attributing climate change mitigation benefits to no-till systems (see Powlson et al. 2014). Nevertheless, in addition to 
Fig. 10 Overall effect on soil C stocks of reduced tillage and effect of each tillage method relative to a deep inversion tillage and $\mathbf{b}$ shallow inversion tillage. Mean values and $95 \%$ confidence intervals of the back-transformed response ratios are shown. Sample sizes (i.e., the number of control-treatment pairs)/number of experiments are shown on the right of the confidence intervals
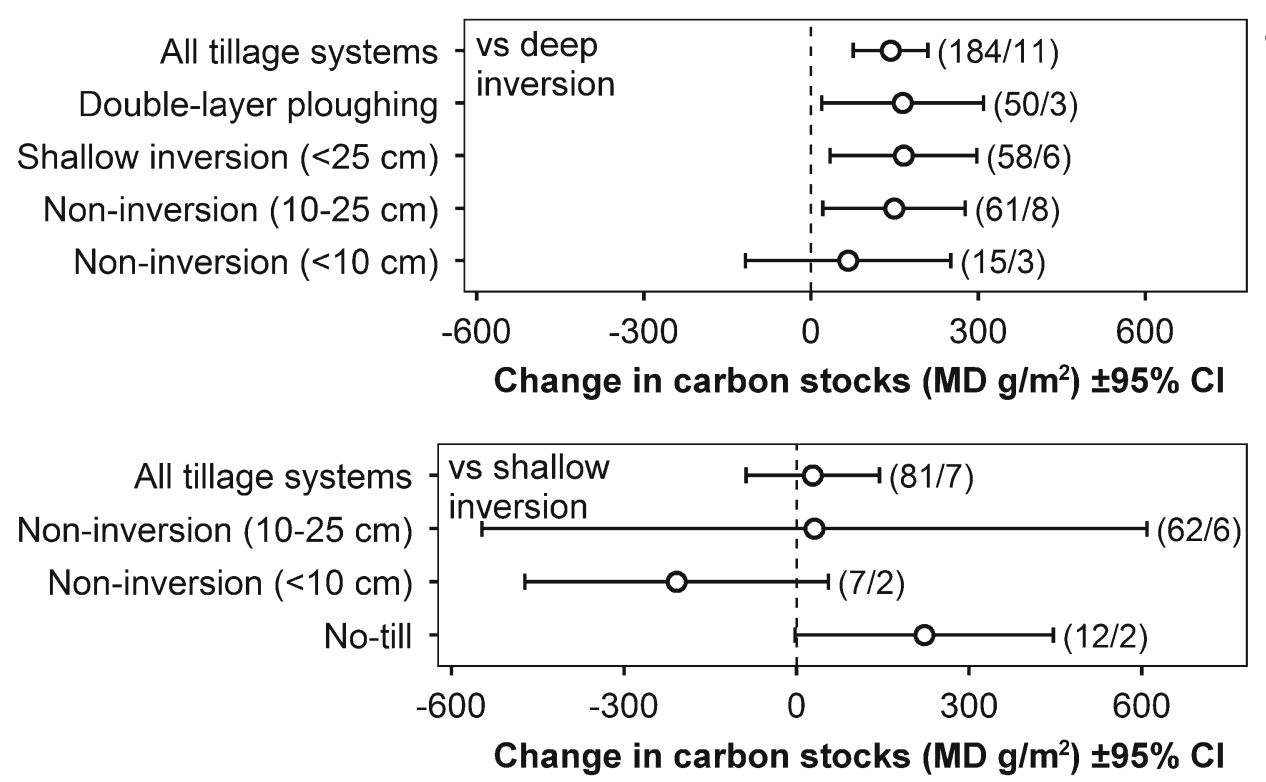

the soil quality and ecosystem service benefits of increased topsoil $\mathrm{C}$, reduced tillage systems also provide an indirect greenhouse gas mitigation service through reductions in fossil fuel energy inputs which can be $20 \mathrm{~kg} \mathrm{C} \mathrm{ha}^{-1}$ year $^{-1}$ lower in conventional systems when converting from deep inversion tillage to no-till (Johnson et al. 2007; Reicosky and Archer 2007).

\section{Conclusions}

The establishment of a sustainable crop rotation is a basic principle of organic farming (Soil Association 2014) and one of the three cornerstones of conservation agriculture. Maintenance of surface cover through residues and cover cropping are also commonly used by many organic farmers at specific stages of the rotation. However, the adoption of minimal soil disturbance through reduced tillage intensity has always been perceived as a major hurdle limiting adoption of the full conservation agriculture package in organic farming systems. The concern has been that crop yields, which can already be lower in organic farming, may be further reduced by weed competition and delayed nutrient mineralization. This analysis has shown that yield reductions do not always occur when tillage is reduced in organic farming. The use of shallow non-inversion methods resulted in no significant decline in yields compared to deep inversion tillage. Shallow inversion tillage also showed promise with minimal reductions in yield $(\sim 5.5 \%)$, non-significant increases in weed incidence, and increased soil $\mathrm{C}$ stocks that provide added benefits from improvements in soil quality and ecosystem service delivery.
For all systems, the relationship between weed incidence and crop yields was not as strong as expected, confirming that other factors such as nutrient supply patterns and soil physical properties may be influencing crop productivity in organic reduced tillage systems.

A useful outcome of this research for practitioners was the evidence showing that the double-layer plough resulted in yields, weed incidence, and soil C stocks similar to the shallow inversion treatment, suggesting that there is no real advantage to the double-layer plough compared with shallow inversion. Shallow inversion tillage may be a relatively easy option for farmers to take up; although depending on soil type and envisaged tillage depth, it may still be necessary for farmers to invest in specialized machinery, such as a skim plough, in order to achieve consistently shallow depths of inversion tillage.

Concerns that weeds always limit crop yields in organic reduced tillage or no-till systems were not confirmed by our study. However, the $\sim 50 \%$ higher levels of weed incidence when tillage was reduced relative to either deep or shallow inversion was cause for concern. Innovative farmers and researchers in Europe and North America are now working to develop organic no-till and rotational tillage systems where cover crops and surface residues are managed to suppress weeds. These systems use mechanical methods of cover crop destruction (e.g., roller crimpers; see Fig. 1b) and no-till drilling equipment in place of herbicides to control weeds (Mirsky et al. 2012). Recent developments like automatic steering technologies for inter-row weed hoeing using a camera proved the effectiveness of this practice to control weeds and to drastically reduce labor (Kunz et al. 2015).The potential of using "complex" crop rotations to manage weeds in organic no-till has also been demonstrated (Anderson 2015). 
In both conventional and organic systems, the use of "strategic tillage" at critical stages in the rotation to manage pernicious perennial weeds or control residue-borne crop diseases may be appropriate (Dang et al. 2015); however, this should be balanced against the negative effects on soil quality. Any form of tillage may result in redistribution of carbon gains to deeper depths and mineralization of labile carbon fractions. This is a particular concern since most of the increases in soil $\mathrm{C}$ concentrations in no-till systems occur in the labile fraction which is most susceptible to mineralization when disturbed (Powlson et al. 2014). Moreover, the stable bio-pores which have been formed by roots and by earthworms are damaged by deep inversion tillage. Our data suggest that temporary shallow inversion tillage is a good compromise, as we also observed carbon gains in this system compared to deep inversion ploughing, with improved weed control relative to the other classes of reduced tillage. By placing the ploughing activities in dry periods, in which vertically burrowing earthworms move to the subsoil, negative effects on earthworms can further be reduced.

Further research is needed to quantify the trade-offs between soil quality and crop productivity in organic reduced tillage systems that use these strategies for weed control. A pragmatic, rather than a dogmatic approach should be implemented to design optimized site-specific systems that will allow the potentially additive benefits of conservation agriculture practices within organic farming systems to be realized.

Acknowledgments The authors wish to acknowledge the efforts of all researchers over the years who set up and maintained the various experiments included in this meta-analysis. This research was carried out within the framework of the TILMAN-ORG project (www.tilman-org.net) funded by CORE Organic II Funding Bodies, being partners of the FP7 ERANet (www.coreorganic2.org).

Open Access This article is distributed under the terms of the Creative Commons Attribution 4.0 International License (http:// creativecommons.org/licenses/by/4.0/), which permits unrestricted use, distribution, and reproduction in any medium, provided you give appropriate credit to the original author(s) and the source, provide a link to the Creative Commons license, and indicate if changes were made.

\section{References}

Amossé C, Jeuffroy M-H, Celette F, Goulevant G, David C (2013) Relayintercropped forage legumes help to control weeds in organic grain production. Eur J Agron 49:158-167

Anderson RL (2015) Integrating a complex rotation with no-till improves weed management in organic farming. A review. Agron Sustain Dev 35(3):967-974. doi:10.1007/s13593-015-0292-3

Angers DA, Eriksen-Hamel NS (2008) Full-inversion tillage and organic carbon distribution in soil profiles: A meta-analysis. Soil Sci Soc Am J 72(5):1370-1374. doi:10.2136/sssaj2007.0342

Armengot L, Berner A, Blanco-Moreno JM, Mäder P, Sans FX (2015) Long-term feasibility of reduced tillage in organic farming. Agron Sustain Dev. doi:10.1007/s13593-014-0249-y
Arvidsson J, Westlin A, Sorensson F (2013) Working depth in noninversion tillage - effects on soil physical properties and crop yield in swedish field experiments. Soil Tillage Res 126:259-266

Arvidsson J, Etana A, Rydberg T (2014) Crop yield in Swedish experiments with shallow tillage and no-tillage 1983-2012. Eur J Agron 52, Part B (0):307-315. doi:10.1016/j.eja.2013.08.002

Baker JM, Ochsner TE, Venterea RT, Griffis TJ (2007) Tillage and soil carbon sequestration-what do we really know? Agric Ecosyst Environ 118(1-4):1-5. doi:10.1016/j.agee.2006.05.014

Bàrberi P (2002) Weed management in organic agriculture: are we addressing the right issues? Weed Res 42:176-193

Bàrberi P (2006) Tillage: how bad is it in organic agriculture? In: Kristiansen P, Taji A, Reganold J (eds) Organic Agriculture: A Global Perspective. pp 295-303.

Bàrberi P, Lo Cascio B (2001) Long-term tillage and crop rotation effects on weed seedbank size and composition. Weed Res 41:325-340

Bender SF, Van Der Heijden MGA (2014) Soil biota enhance agricultural sustainability by improving crop yield, nutrient uptake and reducing nitrogen leaching losses. J Appl Ecol 52:228-239

Bilalis DJ, Karamanos AJ (2010) Organic maize growth and mycorrhizal root colonization response to tillage and organic fertilization. J Sustain Agric 34(8):836-849. doi:10.1080/10440046.2010.519197

Bilalis DJ, Karkanis A, Papastylianou P, Patsiali S, Athanasopoulou M, Barla G, Kakabouki I (2010) Response of organic linseed (Linum usitatissimum L.) to the combination of tillage systems, (minimum, conventional and no-tillage) and fertilization practices: Seed and oil yield production. Aust J Crop Sci 4(9):700-705

Bilalis D, Karkanis A, Patsiali S, Agriogianni M, Konstantas A, Triantafyllidis V (2011) Performance of wheat varieties (Triticum aestivum $\mathrm{L}$.) under conservation tillage practices in organic agriculture. Not Bot Horti Agrobo 39(2):28-33

Bilalis D, Kakabouki I, Karkanis A, Travlos I, Triantafyllidis V, Hela D (2012a) Seed and Saponin production of organic quinoa (Chenopodium quinoa Willd.) for different tillage and fertilization. Not Bot Horti Agrobo 40(1):42-46

Bilalis D, Karkanis A, Pantelia A, Patsiali S, Konstantas A, Efthimiadou A (2012b) Weed populations are affected by tillage systems and fertilization practices in organic flax (Linum usitatissimum L.) crop. Aust J Crop Sci 6(1):157-163

Bronick CJ, Lal R (2005) Soil structure and management: a review. Geoderma 124(1-2):3-22. doi:10.1016/j.geoderma.2004.03.005

Carr PM, Gramig GG, Liebig MA (2013) Impacts of organic zero tillage systems on crops, weeds, and soil quality. Sustainability 5:31723201

Collins D, Corbin A, Benedict C, Cogger C, Bary A, Burrows C, Miles C (2011) Reducing tillage with cover crops in western Washington organic vegetable production: early research progress and future direction. Tilth Producers Q. 21.

Dang YP, Moody PW, Bell MJ, Seymour NP, Dalal RC, Freebairn DM, Walker SR (2015) Strategic tillage in no-till farming systems in Australia's northern grains-growing regions: II. Implications for agronomy, soil and environment. Soil Tillage Res 152:115-123. doi:10.1016/j.still.2014.12.013

Delate K, Cwach D, Butler J (2010) Evaluation of an Organic No-Till System for Organic Corn Production-Neely-Kinyon Farm Trial, 2010. Annual Research Reports-2010 Armstrong Research and Demonstration Farm, Ames, IA, USA

Delate K, Cwach D, Mckern A, Schwarte K (2011) Evaluation of an Organic No-Till System for Organic Corn Production-NeelyKinyon Farm Trial, 2011. Annual Research Reports-2011 Armstrong Research and Demonstration Farm, Ames, IA, USA

Di Tizio A, Lagomarsino A, Moscatelli MC, Marinari S, Mancinelli SGR (2008) The effects of system management on soil carbon dynamics. Lucrari stiintifice, seria B. Horticultura 51:645-650

Diaz-Perez JC, Silvoy J, Phatak SC, Ruberson J, Morse R (2008) Effect of winter cover crops and no-till on the yield of organically-grown 
bell pepper (Capsicum annuum L.). In: Prange RK, Bishop SD (eds) Proceedings of the International Symposium on Sustainability through Integrated and Organic Horticulture. Acta Horticulturae. vol 767. pp 243-247

Dittmann B, Zimmer J (2010) Ökologische Fruchtfolge Güterfelde. In: Schmidt H (ed) Öko-Ackerbau ohne tiefes Pflügen. Praxisbeispiele und Forschungsergebnisse. Verlag Dr. Köster, Berlin, pp 227-231

Emmerling C (2007) Reduced and conservation tillage effects on soil ecological properties in an organic farming system. Biol Agric Hortic 24(4):363-377

Fließbach A, Oberholzer HR, Gunst L, Mäder P (2007) Soil organic matter and biological soil quality indicators after 21 years of organic and conventional farming. Agric Ecosyst Environ 118:273-284

Food and Agriculture Organization of the United Nations (2015) What is conservation agriculture? http://www.fao.org/ag/ca/la.html

Gattinger A, Muller A, Haeni M, Skinner C, Fliessbach A, Buchmann N, Mäder P, Stolze M, Smith P, Scialabba NE-H, Niggli U (2012) Enhanced top soil carbon stocks under organic farming. Proc Natl Acad Sci U S A 109(44):18226-18231

Gruber S, Claupein W (2009) Effect of tillage intensity on weed infestation in organic farming. Soil Tillage Res 105(1):104-111. doi:10. 1016/j.still.2009.06.001

Hedges LV, Gurevitch J, Curtis PS (1999) The meta-analysis of response ratios in experimental ecology. Ecology 80(4):1150-1156

Hoaglin DC, Mosteller F, Tukey JW (2000) Understanding robust and exploratory data analysis. John Wiley \& Sons, New York

Hobbs PR, Sayre KD, Gupta R (2008) The role of conservation agriculture in sustainable agriculture. Philos Trans R Soc Lond Ser B Biol Sci 363:543-555

Jabran K, Mahajan G, Sardana V, Chauhan BS (2015) Allelopathy for weed control in agricultural systems. Crop Prot 72:57-65. doi:10. 1016/j.cropro.2015.03.004

Johnson JM-F, Franzluebbers AJ, Weyers SL, Reicosky DC (2007) Agricultural opportunities to mitigate greenhouse gas emissions. Environ Pollut 150:107-124

Kainz M, Gerl G, Lemnitzer B, Bauchenß J, Hülsbergen K-J (2005) Effects of different tillage systems in the long-term field experiment Scheyern. 8. Wissenschaftstagung Ökologischer Landbau. Kassel, Germany

Koch W, Gaberle K (2010) Extensivierung der Grundbodenbearbeitung in einer auf Marktfruchtbau orientierten Vierfelder-Fruchtfolge (Bernburg). In: Schmidt H (ed) Öko-Ackerbau ohne tiefes Pflügen. Praxisbeispiele und Forschungsergebnisse. Verlag Dr. Köster, Berlin, pp 232-236

Köhl L, Oehl F, Van Der Heijden MGA (2014) Agricultural practices indirectly influence plant productivity and ecosystem services through effects on soil biota. Ecol Appl 24(7):1842-1853. doi:10. 1890/13-1821.1

Krauss M, Berner A, Burger D, Wiemken A, Niggli U, Mäder P (2010) Reduced tillage in temperate organic farming: implications for crop management and forage production. Soil Use Manag 26(1):12-20. doi:10.1111/j.1475-2743.2009.00253.x

Kunz C, Weber JF, Gerhards R (2015) Benefits of precision farming technologies for mechanical weed control in soybean and sugar beet - comparison of precision hoeing with conventional mechanical weed control. Agronomy 5(2):130-142

Lampkin NH, Measures M (2001) Organic farm management handbook, 4th edn. Welsh Institute of Rural Studies University of Wales, Aberystwyth

Lapied E, Nahmani J, Rousseau GX (2009) Influence of texture and amendments on soil properties and earthworm communities. Appl Soil Ecol 43(2-3):241-249. doi:10.1016/j.apsoil.2009.08.004

Légère A, Stevenson F, Benoit D (2011) The selective memory of weed seedbanks after 18 years of conservation tillage. Weed Sci 59:98-106
Lehocka Z, Klimekova M, Bielikova M, Mendel L (2009) The effect of different tillage systems under organic management on soil quality indicators. Agron Res 7(Sp. Iss. 1):369-373

Lewis DB, Kaye JP, Jabbour R, Barbercheck ME (2011) Labile carbon and other soil quality indicators in two tillage systems during transition to organic agriculture. Renewable Agric Food Syst 26(4): 342-353. doi:10.1017/s1742170511000147

Liebman M, Davis AS (2000) Integration of soil, crop, and weed management in low-external-input farming systems. Weed Res 40:27-47

Luna JM (2003) Conservation tillage systems for organic vegetable production. Organic Farming Research Foundation Information Bulletin. 12

Luna JM, Mitchell JP, Shrestha A (2012) Conservation tillage for organic agriculture: Evolution toward hybrid systems in the western USA. Renewable Agric Food Syst 27(1):21-30. doi:10.1017/ s1742170511000494

Luo Z, Wang E, Sun OJ (2010) Can no-tillage stimulate carbon sequestration in agricultural soils? A meta-analysis of paired experiments. Agric Ecosyst Environ 139:224-231

Madden NM, Mitchell JP, Lanini WT, Cahn MD, Herrero EV, Park S, Temple SR, Van Horn M (2004) Evaluation of conservation tillage and cover crop systems for organic processing tomato production. HortTechnology 14(2):243-250

Mäder P, Berner A (2012) Development of reduced tillage systems in organic farming in Europe. Renewable Agric Food Syst 27(1):711. doi: $10.1017 / \mathrm{s} 1742170511000470$

Melander B, Munier-Jolain N, Charles R, Wirth J, Schwarz J, Van Der Weide R, Bonin L, Jensen P, Kudsk P (2013) European perspectives on the adoption of nonchemical weed management in reducedtillage systems for arable crops. Weed Technol 27:231-240

Mirsky SB, Ryan MR, Curran WS, Teasdale JR, Maul J, Spargo JT, Moyer J, Grantham AM, Weber D, Way TR, Camargo GG (2012) Conservation tillage issues: cover crop-based organic rotational notill grain production in the mid-Atlantic region, USA. Renewable Agric Food Syst 27(Special Issue 01):31-40. doi:10.1017/ S1742170511000457

Paffrath A, Stumm C (2010) Systemvergleich wendende und nicht wendende Bodenbearbeitung im Ökologischen Landbau (Auweiler). In: Schmidt H (ed) Öko-Ackerbau ohne tiefes Pflügen. Praxisbeispiele und Forschungsergebnisse. Verlag Dr. Köster, Berlin, pp 252-256

Peigné J, Ball BC, Roger-Estrade J, David C (2007) Is conservation tillage suitable for organic farming? A review. Soil Use Manag 23(2):129-144

Peigné J, Casagrande M, Payet V, David C, Sans FX, Blanco-Moreno JM, Cooper J, Gascoyne K, Antichi D, Bàrberi P, Bigongiali F, Surböck A, Kranzler A, Beeckman A, Willekens K, Luik A, Matt D, Grosse M, Heß J, Maurice Clerc, Dierauer H, Mäder P (2015) How organic farmers practice conservation agriculture in Europe. Renewable Agric Food Syst. doi:10.1017/S1742170514000477

Pittelkow CM, Liang X, Linquist BA, Groenigen KJV, Lee J, Lundy ME, Gestel NV, Six J, Venterea RT, Kessel CV (2014) Productivity limits and potentials of the principles of conservation agriculture. Nature 517:365-368. doi:10.1038/nature13809

Ponisio LC, M'gonigle LK, Mace KC, Palomino J, De Valpine P, Kremen C (2015) Diversification practices reduce organic to conventional yield gap. Proc R Soc Lond Ser B Biol Sci 282:20141396. doi:10. 1098/rspb.2014.1396

Powlson DS, Stirling CM, Jat ML, Gerard BG, Palm CA, Sanchez PA, Cassman KG (2014) Limited potential of no-till agriculture for climate change mitigation. Nat Clim Chang 4(8):678-683. doi:10. 1038/nclimate2292

Quemada M, Baranski M, Lange MNJN-D, Vallejo A, Cooper JM (2013) Meta-analysis of strategies to control nitrate leaching in irrigated agricultural systems and their effects on crop yield. Agric Ecosyst Environ 174:1-10 
R Development Core Team (2011) R: A language and environment for statistical computing. R Foundation for Statistical Computing. http:// www.R-project.org

Reicosky DC, Archer DW (2007) Moldboard plow tillage depth and short-term carbon dioxide release. Soil Tillage Res 94:109-121

Reinicke F, Heyer W, Christen O (2010) Langfristige Wirkungen differenzierter Anbausysteme des Ökologischen Landbaus (Bad Lauchstädt). In: Schmidt H (ed) Öko-Ackerbau ohne tiefes Pflügen. Praxisbeispiele und Forschungsergebnisse. Verlag Dr. Köster, Berlin, Germany, pp 242-246

Seufert V, Ramankutty N, Foley JA (2012) Comparing the yields of organic and conventional agriculture. Nature 485:229-232. doi: http://www.nature.com/nature/journal/vaop/ncurrent/abs/ nature 11069.html\#supplementary-information

Shirtliffe SJ, Johnson EN (2012) Progress towards no-till organic weed control in western Canada. Renewable Agric Food Syst 27(1):60 67. doi:10.1017/s1742170511000500

Silva EM (2014) Screening five fall-sown cover crops for use in organic no-till crop production in the Upper Midwest. Agroecol Sustain Food Sys 38(7):748-763

Soane BD, Ball BC, Arvidsson J, Basch G, Moreno F, Roger-Estrade J (2012) No-till in northern, western and south-western Europe: a review of problems and opportunities for crop production and the environment. Soil Tillage Res 118:66-87. doi:10.1016/j.still.2011. 10.015

Soil Association (2014) Soil Association organic standards farming and growing. Bristol, UK

Soil Survey Division Staff (1993) Soil survey manual. vol Handbook 18 Soil Conservation Service, U.S. Department of Agriculture

Teasdale JR, Mirsky SB, Spargo JT, Cavigelli MA, Maul JE (2012) Reduced-tillage organic corn production in a hairy vetch cover crop. Agron J 104(3):621-628. doi:10.2134/agronj2011.0317
Vaisman I, Entz MH, Flaten DN, Gulden RH (2011) Blade roller-green manure interactions on nitrogen dynamics, weeds, and organic wheat. Agron J 103(3):879-889. doi:10.2134/agronj2010.0437

Vakali C, Zaller JG, Koepke U (2011) Reduced tillage effects on soil properties and growth of cereals and associated weeds under organic farming. Soil Tillage Res 111(2):133-141. doi:10.1016/j.still.2010.09.003

Van den Putte A, Govers G, Diels J, Gillijns K, Demuzere M (2010) Assessing the effect of soil tillage on crop growth: a metaregression analysis on European crop yields under conservation agriculture. Eur J Agron 33(3):231-241. doi:10.1016/j.eja.2010.05. 008

Vian JF, Peigne J, Chaussod R, Roger-Estrade J (2009) Effects of four tillage systems on soil structure and soil microbial biomass in organic farming. Soil Use Manag 25(1):1-10. doi:10.1111/j.1475-2743. 2008.00176.x

Wang Y, Tu C, Cheng L, Li C, Gentry LF, Hoyt GD, Zhang X, Hu S (2011) Long-term impact of farming practices on soil organic carbon and nitrogen pools and microbial biomass and activity. Soil Tillage Res 117:8-16. doi:10.1016/j.still.2011.08.002

West TO, Post WM (2002) Soil organic carbon sequestration rates by tillage and crop rotation: a global data analysis. Soil Sci Soc Am J 66:1930-1946

Wilhelm B, Tiedemann L, Hensel O, Heß J (2011) Grundbodenbearbeitung im Ökolandbau - eine Betriebsumfrage. Paper presented at the Es geht ums Ganze: Forschen im Dialog von Wissenschaft und Praxis, Beiträge zur 11. Wissenschaftstagung Ökologischer Landbau, Justus-Liebig-Universität Gießen, 15-18 Mars 2011

Zanin G, Otto S, Riello L, Borin M (1997) Ecological interpretation of weed flora dynamics under different tillage systems. Agric Ecosyst Environ 66:177-188 